\title{
Chemistry and mineralogy of orthogneisses in the northeastern part of the Moldanubicum
}

\author{
Chemické a minerální složení ortorul severovýchodní části moldanubika
}

(9 figs, 9 tabs)

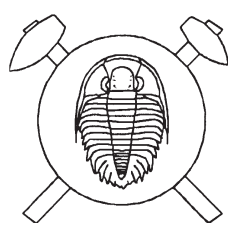

\author{
KAREL BREITER ${ }^{1}$ - RENATA ČOPJAKOVÁ ${ }^{2}-$ ANANDA GABAŠOVÁ $^{1}-$ RADEK ŠKODA ${ }^{2}$ \\ 1 Czech Geological Survey, Geologická 6, CZ-15200 Praha 5, Czech Republic; breiter@cgu.cz
}

2 Institute of Earth Sciences, Masaryk University, Kotlářská 2, CZ-611 37 Brno, Czech Republic

\begin{abstract}
Two principal types of lower Palaeozoic orthogneisses were distinguished in the northeastern part of the Moldanubicum, Bohemian Massif, Czech Republic. Biotite orthogneisses are distributed in outer parts of the area, whereas leucocratic two-mica and muscovite-tourmaline orthogneisses form a SW-NE trending belt running through the entire area. All the rock types are peraluminous. The most fractionated twomica orthogneisses are characterised by enrichment in boron, phosphorus, tin and tungsten and their chemical composition resembles tin granites. Typical mineralogical features comprise P-enrichment of both K-feldspar and albite, common occurrence of tourmaline (schorl) and occasionally phosphorus-enriched almandine-spessartine garnet. Zircon from fractionated orthogneisses is often zoned, and enriched in $\mathrm{P}, \mathrm{U}, \mathrm{Al}, \mathrm{Fe}$ and Sc. Attempt to use monazite for age determination of magmatic precursor of orthogneisses was unsuccessful; all obtained ages are Variscan (316-327 Ma). Nevertheless, from whole-rock chemistry and similarities in mineral composition with the well dated Hluboká orthogneiss it is possible to conclude that all studied rocks are products of one extensive lower Palaeozoic magmatic event, which was important in the northeastern part of the Moldanubicum. This magmatic event produced peraluminous magmas with source probably in metasedimentary formations. Near-minimum melting involving muscovite enriched the primary melt in boron. Successive fractionation led to enrichment in phosphorus and tin. The most fractionated products of this event form a discontinuous belt between the Blaník hill in the southwest and Prribyslavice in the northeast.
\end{abstract}

Key words: orthogneiss; chemistry; petrology; mineralogy; Moldanubicum

\section{Introduction}

Geochemical and mineralogical composition of PreVariscan, probably lower Palaeozoic orthogneisses in Moldanubicum is still poorly understood. Beneš et al. (1963) and Kodym et al. (1963) compiled geological and petrographic data in the explanations to geological maps at the scale of 1:200 000. Němec - Páša (1986) published several analyses of orthogneisses from the northeastern part of Moldanubicum; unfortunately only mean values of major elements from poorly defined rock groups were presented. Povondra et al. (1987) published detailed mineral and chemical data from Přibyslavice orthogneiss, however, the authors did not consistently distinguish samples from the orthogneiss and from associated granite and pegmatite. Later, Slabý (1991) studied orthogneisses in the southwestern part of Moldanubicum and Klečka et al. (1992) published some chemical and mineral data from the Blaník orthogneiss. Povondra - Vrána (1993, 1996) published detailed petrological and mineralogical data and Vrána - Kröner (1995) presented geochronological data from the leucocratic Hluboká orthogneiss. Other investigators focused on structural aspects of the orthogneiss evolution (e.g. Rajlich et al. 1992).

We studied whole-rock chemical composition and mineralogy of biotite and leucocratic orthogneisses in order to define relations among individual orthogneiss bodies and their possible magmatic precursors. We omitted the study of deformation of these rocks, because the original shape of the bodies was completely changed during Variscan event and actual relations between orthogneisses and their envelope give no information about mode of the intrusion (compare Povondra - Vrána 1993).

The studied area extends from the town of Tábor in the SW to the town of Cáslav in the NE, covering the northeastern part of the Bohemian Moldanubicum between the Blanice graben in the $\mathrm{W}$ and the Kutná Hora Crystalline Unit in the E.

\section{Main types of orthogneisses and their geological position}

Two principal types of orthogneisses are traditionally distinguished in the studied area: biotite orthogneisses and leucocratic two-mica (Blaník-type) orthogneisses. Although this division oversimplified the real situation, we follow it in this paper, too.

Biotite ( \pm muscovite) orthogneisses form two discontinuous belts (Fig. 1, Table 1). Bodies at Želiv, Arneštovice, Pacov, Cetoraz and Psárov and several smaller bodies (Beneš et al. 1963) are situated in the southern belt. Bodies at Kácov, Vlastějovice and Římovice form the northern belt. Biotite orthogneisses are generally mediumgrained and well foliated, mineralogically and structurally homogeneous, without visible internal fractionation. Only the largest Želiv body is chemically slightly variable. Biotite is the exclusive mafic phase. Muscovite appears only scarcely, garnet has not been found.

Leucocratic two-mica and muscovite-tourmaline orthogneisses build a discontinuous, generally SW-NE trending belt through the central part of the area. They can be divided into three regional groups. 
Table 1 Main geological features of studied orthogneiss bodies.

\begin{tabular}{|c|c|c|c|}
\hline Name & Area (approx.) & $\begin{array}{l}\text { Orientation } \\
\text { or shape }\end{array}$ & Mineralogy \\
\hline Želiv & $11 \times 1.5 \mathrm{~km}$ & NNE-SSW & $\mathrm{Bt}$ \\
\hline Arneštovice & $3 \times 1 \mathrm{~km}$ & NE-SW & $\mathrm{Bt}(+\mathrm{Ms})$ \\
\hline Pacov & $4 \times 0.5 \mathrm{~km}$ & ENE-WSW & $\mathrm{Bt}$ \\
\hline Cetoraz & $3 \times 1.5 \mathrm{~km}$ & E-W & $\mathrm{Bt}(+\mathrm{Ms})$ \\
\hline Psárov & $1.5 \times 1.5 \mathrm{~km}$ & equant & $\mathrm{Bt}(+\mathrm{Ms})$ \\
\hline Kácov & $4.5 \times 0.5 \mathrm{~km}$ & E-W & $\mathrm{Bt}$ \\
\hline Vlastějovice & $3.5 \times 0.5 \mathrm{~km}$ & NE-SW & $\mathrm{Bt}$ \\
\hline Ř́movice & $1 \times 0.3 \mathrm{~km}$ & E-W & $\mathrm{Bt}$ \\
\hline Choustník & $3 \times 0.5 \mathrm{~km}$ & NE-SW & Bt-Ms \\
\hline Mladá Vožice & $7 \times 1 \mathrm{~km}$ & $\mathrm{~N}-\mathrm{S}$ & Bt-Ms \\
\hline Malý Blaník & $1 \times 1 \mathrm{~km}$ & equant & Bt-Ms \\
\hline Velký Blaník & $1.5 \times 1.5 \mathrm{~km}$ & equant & Bt-Ms \\
\hline Křížov-Pravonín & $6 \times 1 \mathrm{~km}$ & E-W & Bt-Ms, Ms-Tur \\
\hline Javorník-Keblov & $8 \times 1 \mathrm{~km}$ & E-W & Ms-Tur, Ms-Bt \\
\hline Trhový Štěpánov & $1.5 \times 0.5 \mathrm{~km}$ & E-W & Ms-Tur \\
\hline Leština-Sázavka & $\begin{array}{l}\text { group of small } \\
\text { bodies }\end{array}$ & ENE-WSW & Bt-Ms-Tur-Grt \\
\hline Přibyslavice & $\begin{array}{l}8 \mathrm{~km} \text { long belt } \\
\text { of several small } \\
\text { bodies }\end{array}$ & E-W & Bt-Ms-Tur-Grt \\
\hline
\end{tabular}

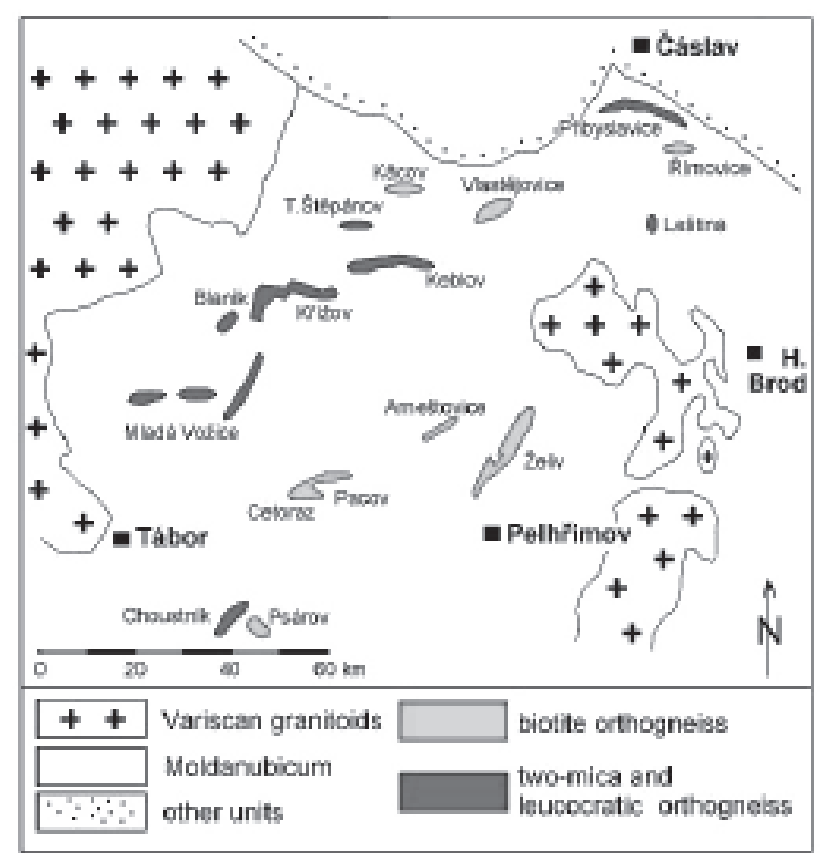

Fig. 1 Sketch map of orthogneiss distribution in the northeastern part of Moldanubicum.

A group of three larger and several smaller bodies between Mladá Vožice in the SW and the Želivka River in the NE includes rocks traditionally termed as "Blaník orthogneiss". Individual bodies in this area have different texture, mineralogy and chemistry, so the term "Blaník orthogneiss" should be better understood geographically than lithologically. The southernmost body at
Mladá Vožice is two-mica orthogneiss, chemically less evolved and well foliated. The central body of Velký Blaník is very inhomogeneous in detail: from fine-grained well foliated two-mica orthogneiss to coarse-grained muscovite-tourmaline metagranite. Garnet appears locally as minor phase (quarries at Křížov and Keblov). The bodies in the NE (at Křížov-Pravonín and Javorník-Keblov) comprise both two-mica and muscovite-tourmaline facies, they are generally less foliated, chemically most evolved and contain small nests of tourmaline-bearing pegmatites (Klečka et al. 1992). In contrast, the tourmaline-muscovite body near Trhový Štěpánov is chemically less evolved. The Choustník two-mica orthogneiss is situated in the SW of studied area. It is in all aspects similar to the Blaník orthogneiss; relicts of porphyritic metagranite were found locally within this orthogneiss (Zikmund 1983).

Several small bodies of mineralogically variable orthogneiss crop out near Sázavka and Leština at the eastern margin of the Moldanubicum. Two-mica, muscovite-tourmaline and muscovite-garnet facies have been found here.

The Pribyslavice orthogneiss is situated at the NE corner of the entire Moldanubicum. It forms about $10 \mathrm{~km}$ long belt of several small bodies elongated E-W. Biotite to two-mica facies forms external bodies at Březí in the $\mathrm{W}$ and at Golčův Jeníkov in the E. The central body at Prribyslavice is formed by chemically more fractionated muscovite-tourmaline \pm garnet facies.

\section{Chemical composition}

Chemical composition of representative samples is characterised by whole-rock analyses presented in Table 2, the relations between important chemical elements in Figs 2-4.

Biotite orthogneisses can be chemically divided into two types. The Si-poor bodies at Rímovice, Psárov, Cetoraz and Želiv $\left(\mathrm{SiO}_{2}\right.$ about 70 wt. \%) are rich in $\mathrm{Fe}(2.2-$ 3.1 wt. $\left.\% \mathrm{Fe}_{2} \mathrm{O}_{3 \text { tot }}\right), \mathrm{Ca}(0.9-1.7$ wt. $\% \mathrm{CaO}), \mathrm{Ba}, \mathrm{Sr}, \mathrm{Zn}$, $\mathrm{Zr}, \mathrm{Th}, \mathrm{V}$, and LREE. The other, Si-richer bodies (73-76 wt. $\left.\% \mathrm{SiO}_{2}\right)$ are poorer in $\mathrm{Fe}\left(1.0-1.5\right.$ wt. $\left.\% \mathrm{Fe}_{2} \mathrm{O}_{3 \text { tot }}\right), \mathrm{Ca}$ $(0.6$ wt. $\% \mathrm{CaO}$ ) and $\mathrm{REE}$, and slightly enriched in $\mathrm{Rb}$. Contents of alkalis, $\mathrm{P}$ and $\mathrm{F}$ are relatively uniform.

The "Blaník" orthogneiss is chemically variable with 72-75 wt. \% $\mathrm{SiO}_{2}$. With increasing $\mathrm{Si}$ the $\mathrm{Al}, \mathrm{Fe}, \mathrm{Ca}$ and P slightly decrease, while $\mathrm{Na}, \mathrm{K}, \mathrm{Rb}, \mathrm{Sr}$ a $\mathrm{Zr}$ are nearly constant. Contents of REE and other compatible elements are much lower and contents of LILE higher than those in biotite orthogneisses.

The Choustník orthogneiss is similar to typical Blaník orthogneiss, the only exception being enrichment in $\mathrm{Rb}$ (up to about $500 \mathrm{ppm}$ ).

Orthogneisses from Leština are chemically homogeneous, in comparison with Blaník orthogneiss slightly richer in $\mathrm{Si}\left(75-76\right.$ wt. \% $\left.\mathrm{SiO}_{2}\right)$ and $\mathrm{K}(4.5-5.0$ wt. \% $\left.\mathrm{K}_{2} \mathrm{O}\right)$ and poor in $\mathrm{Na}\left(3.3-3.5\right.$ wt. $\left.\% \mathrm{Na}_{2} \mathrm{O}\right)$.

Pribyslavice orthogneiss is the most variable body. The $\mathrm{SiO}_{2}$ content increases from 71 wt. \% in biotite-bearing facies at periphery to $73-75$ wt. $\%$ in muscovite facies 

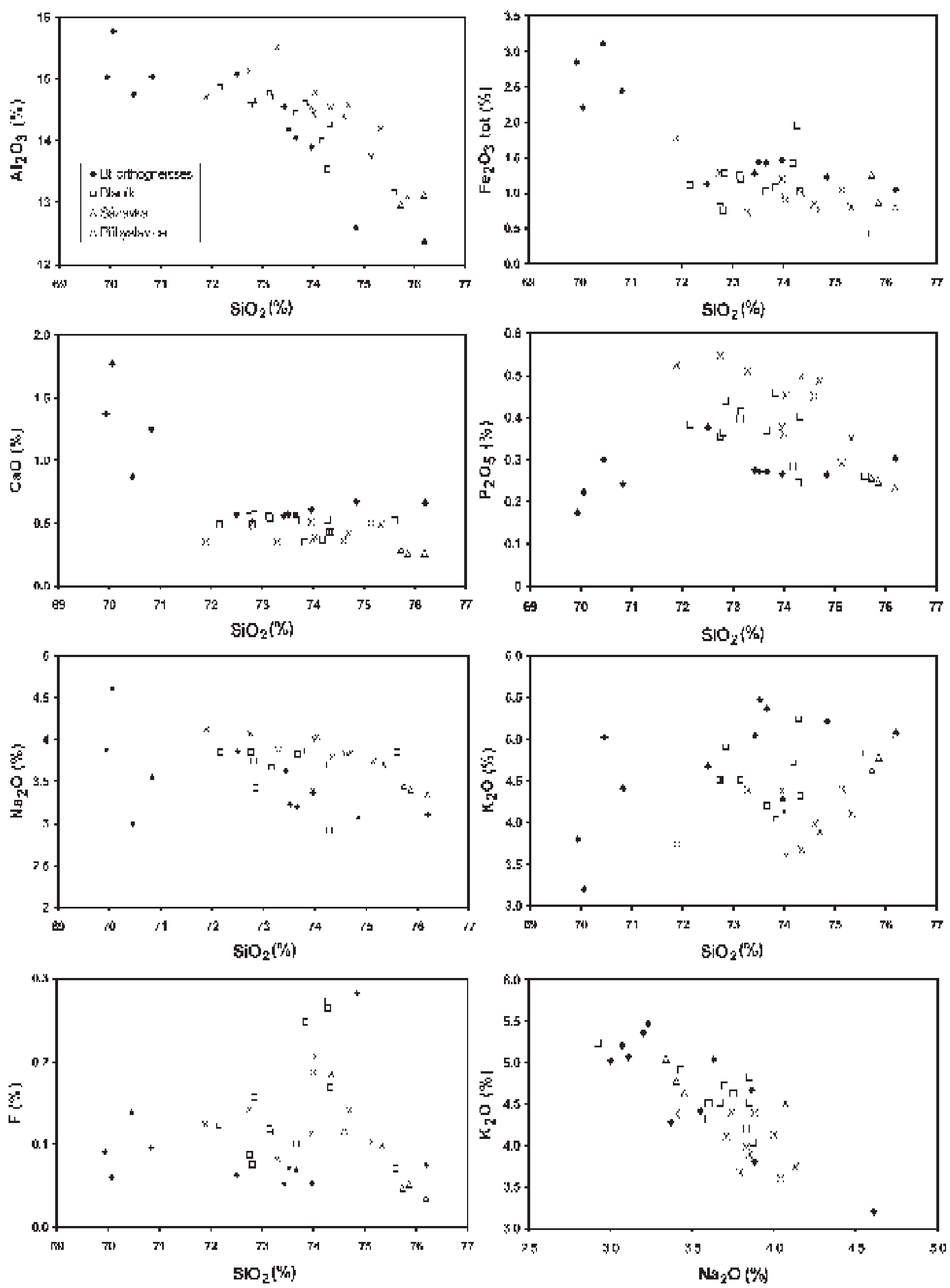

Fig. 2 Harker diagrams and $\mathrm{Na}_{2} \mathrm{O}$ vs. $\mathrm{K}_{2} \mathrm{O}$ of orthogneisses. 

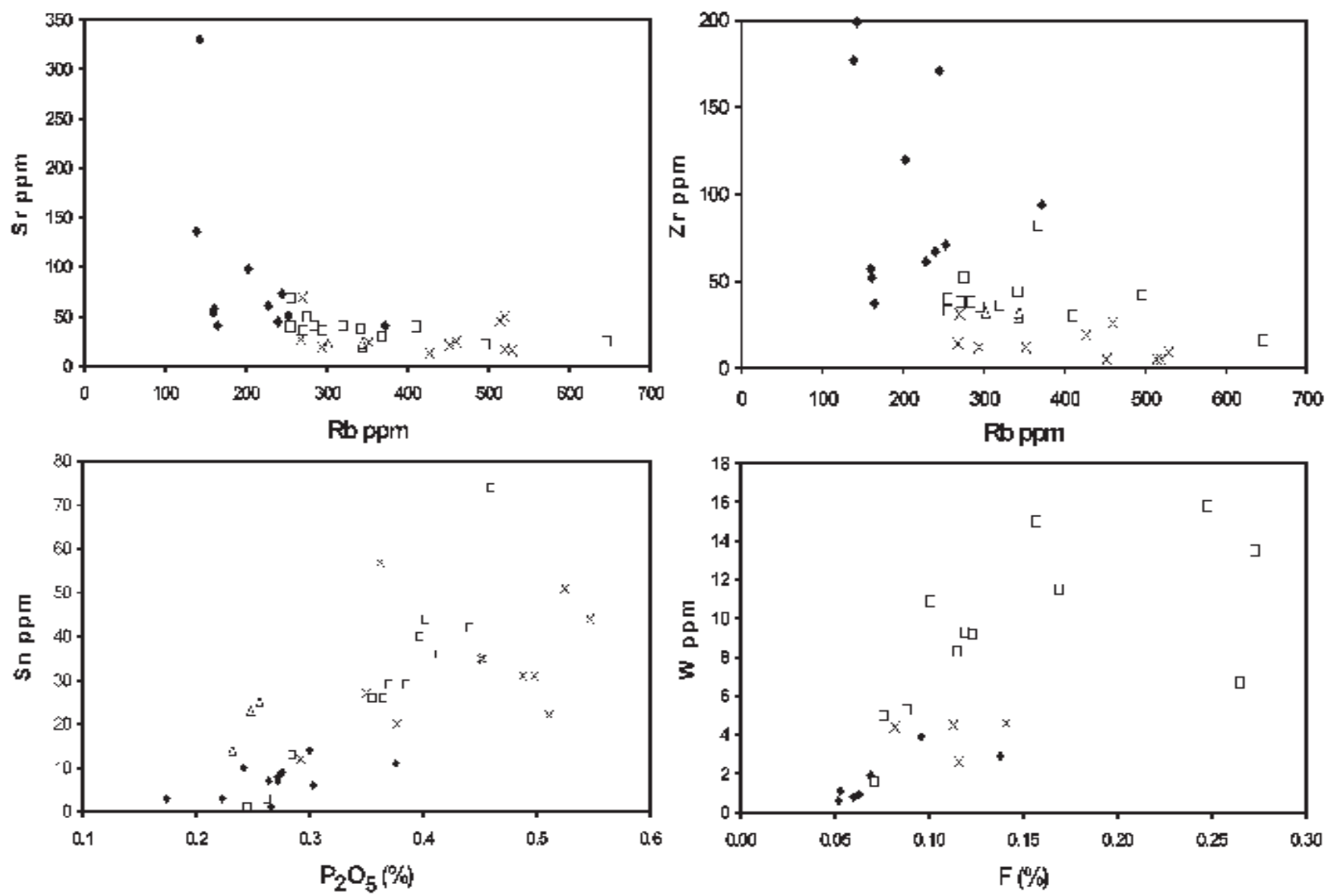

Fig. 3 Trace element contents in orthogneisses.
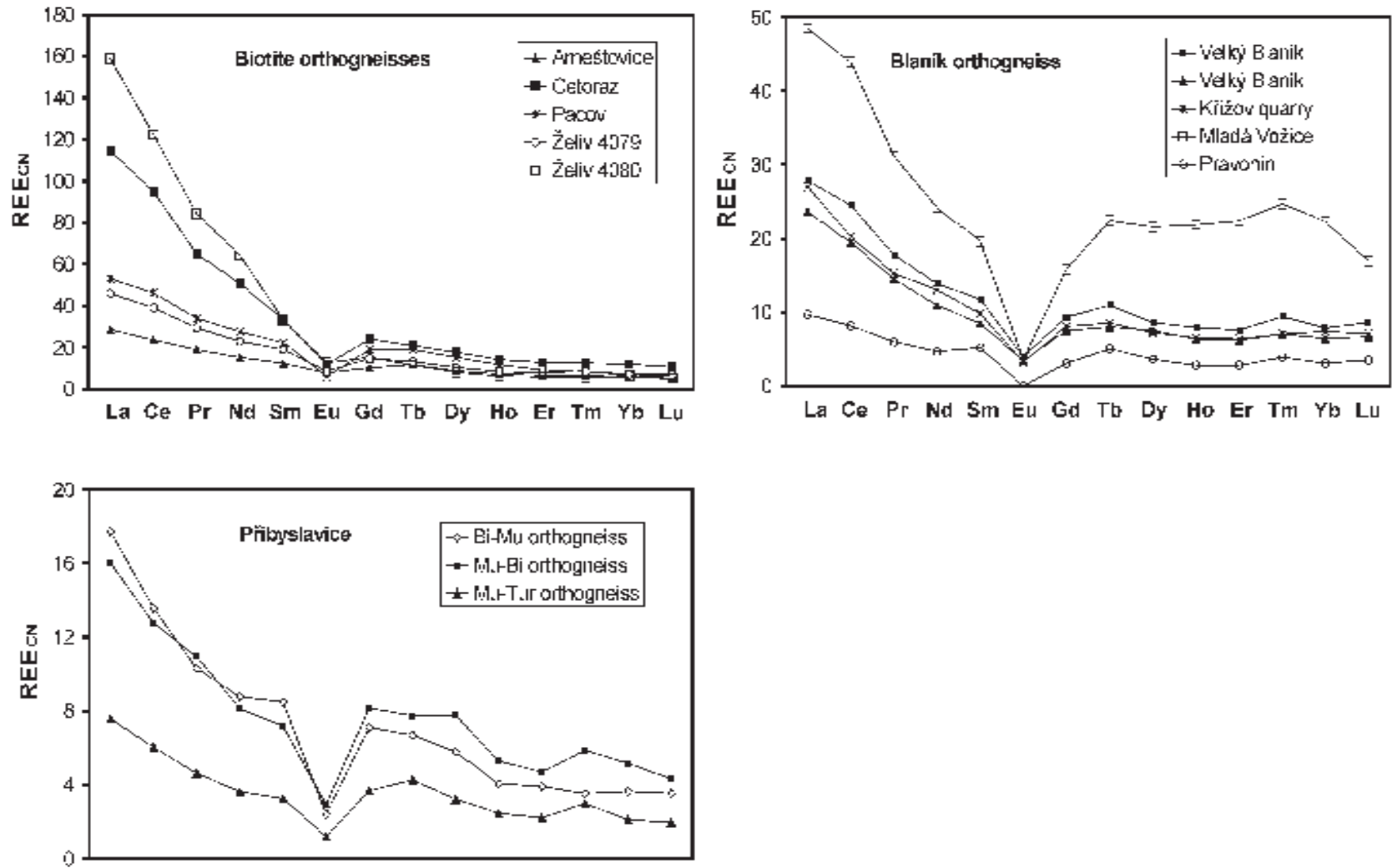

La Ce Pr Hd Sm Eu Gd Tb Dy Ho Er Tm Yb Lu

Fig. 4 Chondrite-normalised REE distribution patterns of orthogneisses. 
Table 2 Chemical composition of orthogneisses. Major elements in wt. \%, trace elements in ppm.

\begin{tabular}{|c|c|c|c|c|c|c|c|c|c|c|c|c|c|c|c|}
\hline $\begin{array}{l}\text { Loca- } \\
\text { lity }\end{array}$ & Želiv & $\begin{array}{c}\text { Ř́mo- } \\
\text { vice }\end{array}$ & $\begin{array}{c}\text { Ceto- } \\
\text { raz }\end{array}$ & $\begin{array}{l}\text { Vlastě- } \\
\text { jovice }\end{array}$ & Kácov & $\begin{array}{l}\text { Mladá } \\
\text { Vožice }\end{array}$ & $\begin{array}{l}\text { Trhový } \\
\text { Štěpánov }\end{array}$ & $\begin{array}{l}\text { Velký } \\
\text { Blanik }\end{array}$ & $\begin{array}{c}\text { Velký } \\
\text { Blanik }\end{array}$ & $\begin{array}{c}\text { Javor- } \\
\text { ník }\end{array}$ & $\begin{array}{c}\text { Sázav- } \\
\text { ka }\end{array}$ & Březí & $\begin{array}{l}\text { Pod- } \\
\text { moky }\end{array}$ & $\begin{array}{l}\text { Přibys- } \\
\text { lavice }\end{array}$ & $\begin{array}{c}\text { Přibys- } \\
\text { lavice }\end{array}$ \\
\hline No. & 4080 & 3775 & 4069 & 3795 & 3806 & 4072 & 3798 & 4074 & 4075 & 4077 & 3484 & 3266 & 3770 & 3262 & 3342 \\
\hline $\mathrm{SiO}_{2}$ & 70.06 & 69.94 & 70.83 & 74.85 & 76.2 & 74.28 & 75.60 & 72.85 & 73.66 & 74.32 & 75.73 & 73.96 & 72.75 & 74.7 & 73.83 \\
\hline $\mathrm{TiO}_{2}$ & 0.35 & 0.33 & 0.31 & 0.14 & 0.10 & 0.16 & 0.04 & 0.13 & 0.14 & 0.11 & 0.08 & 0.10 & 0.06 & 0.04 & 0.05 \\
\hline $\mathrm{Al}_{2} \mathrm{O}_{3}$ & 15.77 & 15.02 & 15.03 & 12.59 & 12.36 & 13.54 & 13.16 & 14.57 & 14.44 & 14.27 & 12.97 & 14.54 & 15.13 & 14.58 & 15.36 \\
\hline $\mathrm{Fe}_{2} \mathrm{O}_{3}$ & 0.880 & 0.740 & 0.480 & 0.260 & 0.410 & 0.500 & 0.190 & 0.480 & 0.340 & 0.410 & 0.348 & 0.165 & 0.410 & 0.369 & 0.233 \\
\hline $\mathrm{FeO}$ & 1.210 & 1.920 & 1.780 & 0.880 & 0.580 & 1.330 & 0.220 & 0.730 & 0.620 & 0.560 & 0.830 & 0.940 & 0.800 & 0.361 & 0.411 \\
\hline MnO & 0.630 & 0.066 & 0.560 & 0.022 & 0.023 & 0.220 & 0.022 & 0.200 & 0.190 & 0.140 & 0.079 & 0.051 & 0.111 & 0.031 & 0.021 \\
\hline MgO & 0.041 & 0.670 & 0.053 & 0.150 & 0.130 & 0.029 & 0.100 & 0.058 & 0.034 & 0.040 & 0.090 & 0.150 & 0.160 & 0.050 & 0.020 \\
\hline $\mathrm{CaO}$ & 1.77 & 1.37 & 1.25 & 0.67 & 0.66 & 0.53 & 0.52 & 0.57 & 0.52 & 0.43 & 0.29 & 0.51 & 0.47 & 0.42 & 0.29 \\
\hline $\mathrm{Li}_{2} \mathrm{O}$ & 0.015 & 0.012 & 0.021 & 0.015 & 0.003 & 0.017 & 0.002 & 0.029 & 0.011 & 0.027 & 0.004 & 0.030 & 0.024 & 0.061 & 0.060 \\
\hline $\mathrm{Na}_{2} \mathrm{O}$ & 4.61 & 3.88 & 3.55 & 3.07 & 3.11 & 2.92 & 3.85 & 3.43 & 3.83 & 3.56 & 3.45 & 3.40 & 4.07 & 3.85 & 4.99 \\
\hline $\mathrm{K}_{2} \mathrm{O}$ & 3.20 & 3.80 & 4.41 & 5.21 & 5.07 & 5.24 & 4.83 & 4.91 & 4.20 & 4.32 & 4.63 & 4.38 & 4.51 & 3.89 & 3.45 \\
\hline $\mathrm{P}_{2} \mathrm{O}_{5}$ & 0.223 & 0.174 & 0.242 & 0.264 & 0.303 & 0.245 & 0.262 & 0.441 & 0.370 & 0.402 & 0.256 & 0.377 & 0.547 & 0.488 & 0.363 \\
\hline $\mathbf{F}$ & 0.060 & 0.091 & 0.096 & 0.282 & 0.075 & 0.265 & 0.071 & 0.157 & 0.101 & 0.169 & 0.047 & 0.113 & 0.142 & 0.141 & 0.117 \\
\hline $\mathrm{H}_{2} \mathrm{O}^{+}$ & 0.840 & 1.020 & 0.780 & 0.650 & 0.600 & 0.920 & 0.410 & 0.950 & 0.990 & 0.750 & 0.478 & 0.783 & 0.740 & 0.627 & 0.539 \\
\hline $\mathrm{H}_{2} \mathrm{O}^{-}$ & 0.12 & 0.20 & 0.05 & 0.12 & 0.10 & 0.06 & 0.10 & 0.08 & 0.14 & 0.06 & 0.09 & 0.09 & 0.08 & 0.05 & 0.06 \\
\hline Total & 99.77 & 99.23 & 99.45 & 99.18 & 99.72 & 100.25 & 98.83 & 99.59 & 99.59 & 99.57 & 99.36 & 99.57 & 100.00 & 99.63 & 99.77 \\
\hline As & 5 & 6 & 6 & 5 & 4 & 11 & 4 & 5 & 5 & 5 & 8 & $<7$ & 7 & 18 & 8 \\
\hline B & 10 & & 9 & & & 11 & 405 & 546 & 49 & 789 & & 190 & 833 & 822 & \\
\hline $\mathbf{B a}$ & 891 & & 503 & & & 112 & 222 & 126 & 194 & 100 & & 80 & 79 & 5 & \\
\hline Be & 3 & & 1 & & & 2 & $<0.5$ & 3 & $<1$ & $<1$ & & & 1 & & \\
\hline Co & 3 & & 3 & & & 1 & & 1 & 1 & 1 & & $<0.5$ & & $<0.5$ & \\
\hline Cs & 5 & & 16 & & & 18 & 1 & 46 & 19 & 22 & & 19 & 11 & 14 & \\
\hline $\mathrm{Cu}$ & 6 & 7 & 6 & 5 & 5 & 4 & 3 & 4 & 4 & 4 & 11 & $<7$ & 4 & $<7$ & 5 \\
\hline Ga & 22 & & 21 & & & 21 & 20 & 22 & 20 & 22 & & 23 & 26 & 31 & \\
\hline Hf & 5 & & 4 & & & 3 & 3 & 2 & 2 & 2 & & 2 & 1 & 2 & \\
\hline Nb & 9 & 14 & 13 & 14 & 10 & 12 & 13 & 14 & 12 & 15 & 8 & 17 & 23 & 19 & 20 \\
\hline $\mathbf{P b}$ & 19 & 19 & 19 & $<2$ & 6 & 4 & 4 & 14 & 11 & 7 & 9 & 15 & 6 & $<7$ & $<2$ \\
\hline $\mathbf{R b}$ & 143 & 139 & 203 & 372 & 228 & 368 & 275 & 342 & 256 & 410 & 344 & 294 & 460 & 520 & 571 \\
\hline Sn & 3 & 3 & 10 & 7 & 6 & $<2$ & 3 & 42 & 29 & 44 & 25 & 20 & 44 & 31 & 50 \\
\hline $\mathrm{Sr}$ & 330 & 136 & 98 & 41 & 61 & 30 & 50 & 38 & 69 & 40 & 19 & 19 & 25 & 17 & 19 \\
\hline Ta & 1 & & 2 & & & 2 & 3 & 4 & 2 & 4 & & 2 & 4 & 1 & \\
\hline Th & 18 & 15 & 12 & 18 & 10 & 13 & 12 & 4 & 6 & 5 & & 1.5 & 2 & 0.6 & 0.4 \\
\hline $\mathbf{U}$ & 5 & 4 & 3 & 8 & 6 & 5 & 10 & 5 & $<2$ & 6 & 4 & 6.1 & 4 & 6.5 & 3.5 \\
\hline $\mathbf{V}$ & 23 & & 23 & & & 6 & $<5$ & $<5$ & 5 & $<5$ & & $<5$ & $<5$ & $<5$ & \\
\hline $\mathbf{W}$ & 1 & & 4 & & & 7 & 2 & 15 & 11 & 12 & & 5 & 5 & 5 & \\
\hline $\mathrm{Zn}$ & 60 & 57 & 84 & 30 & 30 & 49 & 17 & 70 & 36 & 61 & 42 & 43 & 6 & 46 & 81 \\
\hline $\mathbf{Z r}$ & 199 & 177 & 120 & 94 & 61 & 82 & 52 & 44 & 33 & 30 & 29 & 12 & 26 & 5 & 11 \\
\hline $\mathbf{Y}$ & 11.10 & 28.60 & 25.00 & 42.60 & 23.00 & 37.10 & 14.10 & 14.60 & 12.20 & 9.40 & 6.20 & 10.40 & 7.50 & 4.00 & 3.00 \\
\hline La & 37.70 & 35.70 & 27.20 & 12.60 & 5.70 & 11.50 & 2.10 & 6.60 & 5.60 & 4.50 & 2.30 & 3.80 & 4.20 & 1.00 & 0.80 \\
\hline $\mathrm{Ce}$ & 74.90 & 77.90 & 58.10 & 34.60 & 14.10 & 26.90 & 4.50 & 15.00 & 11.90 & 9.50 & 5.00 & 7.80 & 8.30 & 2.40 & 2.10 \\
\hline Pr & 8.01 & 7.80 & 6.18 & 3.30 & 2.00 & 2.96 & 0.58 & 1.69 & 1.38 & 1.16 & $<0.70$ & 1.04 & 0.98 & 0.29 & \\
\hline Nd & 30.00 & 30.30 & 23.70 & 14.30 & 6.40 & 11.30 & 2.20 & 6.50 & 5.10 & 4.70 & $<2.00$ & 3.80 & 4.10 & 0.90 & \\
\hline Sm & 5.10 & 6.94 & 5.10 & 4.19 & 2.14 & 3.00 & 1.00 & 1.80 & 1.30 & 1.20 & 0.54 & 1.10 & 1.30 & 0.60 & 0.54 \\
\hline $\mathbf{E u}$ & 0.73 & 0.96 & 0.69 & 0.70 & 0.31 & 0.21 & 0.06 & 0.23 & 0.20 & 0.13 & $<0.08$ & 0.17 & 0.14 & $<0.05$ & \\
\hline Gd & 3.12 & 5.81 & 4.92 & 4.59 & 2.37 & 3.26 & 1.25 & 1.92 & 1.55 & 1.18 & 0.70 & 1.68 & 1.46 & 0.75 & 0.69 \\
\hline Tb & 0.43 & $<0.70$ & 0.78 & $<0.70$ & $<0.70$ & 0.84 & 0.31 & 0.41 & 0.30 & 0.26 & $<0.70$ & 0.29 & 0.25 & 0.13 & \\
\hline Dy & 2.05 & 5.27 & 4.50 & 7.58 & 4.00 & 5.49 & 2.12 & 2.19 & 1.92 & 1.62 & 1.05 & 1.97 & 1.47 & 0.75 & 0.70 \\
\hline Но & 0.35 & 1.11 & 0.80 & 1.38 & 0.56 & 1.24 & 0.43 & 0.45 & 0.36 & 0.30 & $<0.50$ & 0.30 & 0.23 & 0.11 & \\
\hline $\mathbf{E r}$ & 0.96 & 3.86 & 2.12 & 6.00 & 2.68 & 3.71 & 1.49 & 1.26 & 1.03 & 0.91 & $<0.40$ & 0.78 & 0.65 & 0.33 & \\
\hline Tm & 0.14 & 0.52 & 0.32 & 0.78 & 0.53 & 0.63 & 0.25 & 0.24 & 0.18 & 0.14 & $<0.30$ & 0.15 & 0.09 & $<0.05$ & \\
\hline $\mathbf{Y b}$ & 1.09 & 3.00 & 2.03 & 5.04 & 2.94 & 3.79 & 1.84 & 1.34 & 1.10 & 0.97 & 1.13 & 0.88 & 0.62 & 0.52 & 0.40 \\
\hline Lu & 0.13 & 0.37 & 0.27 & 0.58 & 0.38 & 0.43 & 0.24 & 0.22 & 0.17 & 0.16 & 0.17 & 0.11 & 0.09 & 0.08 & 0.06 \\
\hline
\end{tabular}


in the centre. Contents of $\mathrm{Fe}$ and $\mathrm{P}$ decrease with increasing $\mathrm{SiO}_{2}$; $\mathrm{Fe}$ decreases due to disappearance of biotite, $\mathrm{P}$ due to decrease of $\mathrm{K}$-feldspar (the main P-host), in the domains of the intrusion most enriched in quartz. Contents of alkalis are very variable and reflect changes in the ratio between $\mathrm{K}$-feldspar and albite in the muscovite facies. Contents of compatible trace elements $\mathrm{Sr}, \mathrm{Zr}$, Th and REE are low, namely in the muscovite-tourmaline facies. Among lithophile elements, $\mathrm{Rb}$ and $\mathrm{Sn}$ have tendency to strong enrichment $(200 \rightarrow 600 \mathrm{ppm}$ and $10 \rightarrow 60 \mathrm{ppm}$, respectively), while $\mathrm{F}$ and $\mathrm{Li}$ are relatively low $\left(0.1-0.2\right.$ wt. \% F, 0.02-0.06 wt. \% $\left.\mathrm{Li}_{2} \mathrm{O}\right)$.

All orthogneisses are generally peraluminous with aluminium saturation index (ASI) 1.15-1.30. Less peraluminous (ASI $=1.05)$ are only the quartz-rich and mica-poor varieties of both biotite and leucocratic types of orthogneisses (Vlastějovice, Kácov and Trhový Štěpánov).

Boron is typically enriched in two-mica orthogneisses, with abundances ranging between 300 and 1200 ppm. There are no clear correlations between boron and $\mathrm{F}$ or $\mathrm{P}$ contents.

\section{Mineralogy}

\section{Feldspars}

Plagioclase and K-feldspar are, together with quartz, the main constituents of all studied rocks. The less siliceous biotite orthogneisses contain P-free oligoclase (An13-20) and $\mathrm{P}$-poor K-feldspar with max. of 0.1 wt. $\% \mathrm{P}_{2} \mathrm{O}_{5}$.

Albite and K-feldspar in two-mica and muscovite orthogneisses are enriched in phosphorus: albite contains about $0.3-0.5$ wt. $\% \mathrm{P}_{2} \mathrm{O}_{5}$, K-feldspar about $0.5-0.8$ wt. \% $\mathrm{P}_{2} \mathrm{O}_{5}$. Texture of both feldspars, together with their high content of phosphorus, indicate that feldspars survived the Variscan metamorphism without significant changes of composition.

\section{Micas}

Micas, biotite and/or muscovite, play important role in all studied orthogneisses. Biotite is the most important carrier of Fe, Mg, Mn and Ti. Among trace elements, both micas are major host of F, Li and $\mathrm{Zn}$, and important host of $\mathrm{Rb}, \mathrm{Cs}$ and Be (Tables 3 and 4).

All biotites (Fig. 5a) should be termed as annite. $\mathrm{Fe} / \mathrm{Mg}$-ratio and ${ }^{\mathrm{IV}} \mathrm{Si}$-occupancy varied among individual samples only slightly. Remarkable is the finding that there is no difference in contents of major elements between annites from the biotite orthogneisses and those from the two-mica orthogneisses. Of course, important differences are observed in minor elements: Li, Rb, Cs, $\mathrm{Zn}$ and $\mathrm{F}$ are enriched and $\mathrm{Ba}, \mathrm{Be}$ and $\mathrm{V}$ depleted in biotite from the most fractionated muscovite orthogneisses in comparison with biotite from biotite orthogneisses (Fig. 5c).

Muscovite occurs as an accessory phase in some biotite orthogneisses and becomes a major phase in the two-mica and muscovite-tourmaline orthogneisses. In biotite orthogneisses, muscovite is relatively Mg-rich and
Si-poor, in leucocratic orthogneisses muscovite becomes Fe-rich and sometimes also Si-richer (Fig. 5b).

In comparison with associated biotites, muscovites in all orthogneisses are relatively Mg-enriched. Among trace elements, contents of $\mathrm{Rb}$ in muscovite are well comparable with those in biotite, but $\mathrm{Li}, \mathrm{Cs}, \mathrm{F}$ and $\mathrm{Zn}$ are systematically more enriched in biotite.

\section{Tourmaline}

Tourmaline is present only in the most leucocratic and peraluminous types of orthogneisses, generally as the exclusive Fe-Mg-bearing mineral in association with muscovite (Trhový Štěpánov, Javorník, Přibyslavice). In the less fractioned part of the Prribyslavice orthogneiss at Golčův Jeníkov, only accessory tourmaline in association with scarce biotite has been found. Where tourmaline occurs in association with garnet (Přibyslavice), the garnet is clearly younger.

All tourmalines should be classified as schorl (Table 5, Fig. 6). Schorl is relatively rich in $\mathrm{Al}$, total $\mathrm{Al}$ is 6.0-7.0 apfu. Some Al probably enters the T-site (usually 0.1-0.2 apfu, max. $0.3 \mathrm{apfu}$ ), the Z-site is fully occupied by $\mathrm{Al}$ and ${ }^{\mathrm{Y}} \mathrm{Al}$ is $0.0-0.8$. In the $\mathrm{X}$-site, $\mathrm{Na}(0.7-0.9$ apfu.) clearly prevails above the vacancies $(0.1-0.3 \mathrm{apfu})$ and $\mathrm{Ca}(<0.04$ apfu); only tourmaline from Trhový Štěpánov contains about 0.1 apfu $\mathrm{Ca}$ (Fig. 6a). The most variegated is the occupancy of Y-site: content of $\mathrm{Al}$ ranges from less than 0.1 atoms (Trhový Štěpánov) to 0.4-0.7 atoms (Přibyslavice), while the $\mathrm{Fe} / \mathrm{Fe}+\mathrm{Mg}$-ratio increases from 0.6-0.7 in Trhový Štěpánov and Golčův Jeníkov, to 0.9-0.95 in Přibyslavice (Figs 6 b, c). ${ }^{\mathrm{Y}} \mathrm{Al}$ correlates negatively with $\mathrm{Mg}$.

Taken together, tourmaline evolved from relatively Al, Na-poor, Mg-enriched, to Al, Na, Fe-enriched schorl.

\section{Garnet}

Garnet is a common accessory to minor phase in some two-mica orthogneiss bodies. Its position in crystallisation sequence varies from the early crystallised disseminated accessory grains (two-mica orthogneis of the Blaník type in the Keblov quarry) through the late magmatic (?) crystallisation of quartz-garnet nodules (Leština, Prribyslavice) to late metamorphic crystallisation on shear-zones cutting the foliation (two-mica orthogneiss of the Blaník type in the Krrížov quarry).

All analysed garnets are almandine with 10-20\% of spessartine component. Contents of grossular and pyrope components are low to negligible (together always $<5$ mol.\%). A characteristic feature of all garnets from studied Moldanubian orthogneisses is enrichment in phosphorus, usually between 0.1 and 0.4 wt. $\% \mathrm{P}_{2} \mathrm{O}_{5}$. The substitution $\square+2 \mathrm{P} \leftrightarrow \mathrm{R}^{2+}+2 \mathrm{Si}$ and/or alluaudite-type substitution $\mathrm{Na}+\square+3 \mathrm{P} \leftrightarrow 2 \mathrm{R}^{2+}+3 \mathrm{Si}$ seem the most likely mechanisms of phosphorus incorporation in garnet structure (Breiter et al. 2005). Yttrium concentration is usually below detection limit (350 ppm). Garnets are only slightly zoned with relatively $\mathrm{Mn}(+\mathrm{Ca}, \mathrm{Mg}, \mathrm{P})$-enriched core and $\mathrm{Fe}$-enriched rim.

In biotite orthogneisses, garnet has not been found. 
Table 3 Chemical composition (wt. \%) and empirical formulae (based on 46 positive charges) of micas.

\begin{tabular}{|c|c|c|c|c|c|c|c|c|c|c|c|c|c|c|c|c|}
\hline Mica & Ms & Ms & Ms & Ms & Ms & Ms & Ms & Bt & Bt & Bt & Bt & Bt & Bt & Bt & Bt & Bt \\
\hline $\begin{array}{l}\text { Loca- } \\
\text { lity }\end{array}$ & $\begin{array}{l}\text { Psá- } \\
\text { rov }\end{array}$ & $\begin{array}{c}\text { Malý } \\
\text { Blaník }\end{array}$ & $\begin{array}{l}\text { Mladá } \\
\text { Vožice }\end{array}$ & $\begin{array}{c}\text { Keb- } \\
\text { lov }\end{array}$ & $\begin{array}{l}\text { Trhový } \\
\text { Štěpánov }\end{array}$ & $\begin{array}{l}\text { Pod- } \\
\text { moky }\end{array}$ & $\begin{array}{l}\text { Přibys- } \\
\text { lavice }\end{array}$ & Želiv & $\begin{array}{l}\text { Psá- } \\
\text { rov }\end{array}$ & $\begin{array}{l}\text { Vlastě- } \\
\text { jovice }\end{array}$ & $\begin{array}{c}\text { Ceto- } \\
\text { raz }\end{array}$ & $\begin{array}{l}\text { Mladá } \\
\text { Vožice }\end{array}$ & $\begin{array}{l}\text { Chou- } \\
\text { stník }\end{array}$ & $\begin{array}{c}\text { Keb- } \\
\text { lov }\end{array}$ & $\begin{array}{l}\text { Pod- I } \\
\text { moky }\end{array}$ & $\begin{array}{l}\text { Přibys- } \\
\text { lavice }\end{array}$ \\
\hline Sample & 4066 & 4073 & 4072 & 3796 & 3798 & 3770 & 3264 & 4080 & 4066 & 3795 & 4069 & 4072 & 4065 & 3796 & 3770 & 3266 \\
\hline $\mathrm{SiO}_{2}$ & 45.72 & 46.57 & 46.75 & 45.56 & 46.93 & 46.36 & 45.20 & 35.30 & 34.57 & 35.78 & 34.21 & 35.18 & 35.66 & 34.48 & 33.97 & 34.24 \\
\hline $\mathrm{Al}_{2} \mathrm{O}_{3}$ & 35.26 & 35.34 & 33.32 & 34.40 & 29.57 & 33.14 & 33.64 & 18.17 & 19.15 & 17.91 & 19.62 & 18.65 & 19.56 & 19.53 & 20.08 & 20.18 \\
\hline $\mathrm{TiO}_{2}$ & 1.03 & 0.35 & 0.37 & 0.70 & 1.23 & 0.53 & 0.14 & 3.17 & 3.030 & 2.68 & 2.56 & 1.14 & 2.32 & 2.28 & 2.04 & 2.64 \\
\hline $\mathrm{FeO}$ & 0.88 & 1.44 & 2.96 & 1.69 & 3.85 & 2.21 & 3.05 & 21.16 & 21.31 & 26.96 & 22.19 & 27.72 & 24.55 & 23.80 & 24.95 & 25.75 \\
\hline MgO & 0.53 & 0.59 & 0.96 & 0.75 & 1.75 & 0.82 & 0.51 & 7.61 & 6.46 & 2.49 & 6.16 & 3.00 & 2.28 & 4.09 & 3.17 & 2.39 \\
\hline $\mathrm{MnO}$ & 0.00 & 0.00 & 0.00 & 0.13 & 0.01 & 0.08 & 0.28 & 0.27 & 0.40 & 0.35 & 0.38 & 0.52 & 0.53 & 0.40 & 0.43 & 0.48 \\
\hline $\mathrm{CaO}$ & 0.02 & 0.00 & 0.02 & 0.00 & 0.00 & 0.00 & 0.00 & 0.00 & 0.00 & 0.00 & 0.00 & 0.00 & 0.01 & 0.05 & 0.00 & 0.00 \\
\hline $\mathrm{BaO}$ & 0.01 & 0.00 & 0.00 & 0.02 & 0.09 & 0.04 & n.a. & 0.19 & 0.00 & 0.05 & 0.00 & 0.11 & 0.01 & 0.05 & 0.00 & \\
\hline $\mathrm{Na}_{2} \mathrm{O}$ & 0.60 & 0.53 & 0.55 & 0.72 & 0.48 & 0.63 & 0.96 & 0.10 & 0.07 & 0.10 & 0.13 & 0.07 & 0.08 & 0.14 & 0.06 & 0.41 \\
\hline $\mathrm{K}_{2} \mathrm{O}$ & 10.67 & 10.27 & 10.18 & 10.44 & 10.43 & 10.46 & 10.34 & 9.79 & 9.78 & 9.81 & 9.73 & 9.39 & 9.71 & 9.40 & 9.35 & 9.19 \\
\hline Total & 94.72 & 95.12 & 95.13 & 94.44 & 94.37 & 94.35 & 94.10 & 95.76 & 94.75 & 96.14 & 94.99 & 95.79 & 94.76 & 94.26 & 94.13 & 95.27 \\
\hline Si & 6.122 & 6.195 & 6.273 & 6.147 & 6.410 & 6.269 & 6.171 & 5.423 & 5.369 & 5.615 & 5.324 & 5.557 & 5.597 & 5.435 & 5.390 & 5.384 \\
\hline Al & 5.565 & 5.542 & 5.270 & 5.471 & 4.761 & 5.281 & 5.413 & 3.291 & 3.505 & 3.312 & 3.598 & 3.472 & 3.618 & 3.628 & 3.756 & 3.741 \\
\hline $\mathbf{T i}$ & 0.104 & 0.035 & 0.038 & 0.071 & 0.126 & 0.054 & 0.014 & 0.366 & 0.354 & 0.316 & 0.300 & 0.135 & 0.274 & 0.270 & 0.243 & 0.312 \\
\hline $\mathrm{Fe}$ & 0.098 & 0.160 & 0.332 & 0.190 & 0.440 & 0.250 & 0.348 & 2.719 & 2.768 & 3.539 & 2.888 & 3.662 & 3.222 & 3.138 & 3.311 & 3.386 \\
\hline Mg & 0.105 & 0.117 & 0.193 & 0.151 & 0.355 & 0.166 & 0.103 & 1.743 & 1.496 & 0.583 & 1.430 & 0.706 & 0.534 & 0.962 & 0.750 & 0.561 \\
\hline Mn & 0.000 & 0.000 & 0.000 & 0.015 & 0.001 & 0.010 & 0.032 & 0.036 & 0.052 & 0.047 & 0.050 & 0.070 & 0.071 & 0.054 & 0.057 & 0.064 \\
\hline $\mathrm{Ca}$ & 0.002 & 0.000 & 0.003 & 0.001 & 0.000 & 0.000 & 0.000 & 0.000 & 0.000 & 0.000 & 0.000 & 0.000 & 0.002 & 0.008 & 0.000 & 0.000 \\
\hline $\mathbf{B a}$ & 0.000 & 0.000 & 0.000 & 0.001 & 0.005 & 0.002 & 0.000 & 0.012 & 0.000 & 0.003 & 0.000 & 0.007 & 0.001 & 0.004 & 0.000 & 0.000 \\
\hline $\mathrm{Na}$ & 0.155 & 0.136 & 0.144 & 0.189 & 0.128 & 0.166 & 0.254 & 0.031 & 0.022 & 0.031 & 0.039 & 0.023 & 0.024 & 0.042 & 0.019 & 0.126 \\
\hline $\mathbf{K}$ & 1.823 & 1.743 & 1.742 & 1.798 & 1.817 & 1.805 & 1.801 & 1.919 & 1.938 & 1.963 & 1.932 & 1.893 & 1.943 & 1.890 & 1.892 & 1.843 \\
\hline
\end{tabular}

Table 4 Trace elements in biotite from orthogneisses ( $\mathrm{F}$ and $\mathrm{Li}_{2} \mathrm{O}$ in wt. \%, other in ppm).

\begin{tabular}{|l|c|ccrrrrrrr|}
\hline Locality & $\mathbf{N o .}$ & $\mathbf{F}$ & $\mathbf{L i}_{2} \mathbf{O}$ & $\mathbf{S r}$ & $\mathbf{B a}$ & $\mathbf{V}$ & $\mathbf{B e}$ & $\mathbf{Z n}$ & $\mathbf{R b}$ & $\mathbf{C s}$ \\
\hline Želiv & $\mathbf{4 0 7 9}$ & 0.33 & 0.19 & 9 & 101 & 55 & 1.5 & 765 & 826 & 83 \\
Zeliv & $\mathbf{4 0 8 0}$ & 0.47 & 0.14 & 35 & 616 & 142 & 5.9 & 564 & 818 & 50 \\
Psárov & $\mathbf{4 0 6 6}$ & 0.70 & 0.13 & 4 & 205 & 185 & 0.9 & 506 & 1089 & 126 \\
Bácovice & $\mathbf{4 0 6 7}$ & 0.36 & 0.10 & 17 & 111 & 107 & 1.3 & 567 & 475 & 35 \\
Cetoraz & $\mathbf{4 0 6 9}$ & 0.61 & 0.18 & 3 & 247 & 188 & $<0.8$ & 838 & 1148 & 131 \\
Pacov & $\mathbf{4 0 7 1}$ & 0.53 & 0.21 & 8 & 87 & 42 & $<0.8$ & 843 & 1117 & 132 \\
Vlastějovice & $\mathbf{3 7 9 5}$ & 2.88 & 0.18 & 6 & 103 & 35 & 2.1 & 549 & 2256 & 73 \\
Kácov & $\mathbf{3 8 0 6}$ & 0.85 & 0.05 & 8 & 149 & 22 & $<0.8$ & 577 & 1366 & 21 \\
Choustník & $\mathbf{4 0 6 5}$ & 2.45 & 0.56 & 4 & 62 & 71 & 1.6 & 622 & 3161 & 686 \\
Mladá Vožice & $\mathbf{4 0 7 2}$ & 1.83 & 0.17 & 3 & 91 & 36 & 1.5 & 635 & 2064 & 202 \\
Malý Blanik & $\mathbf{4 0 7 3}$ & 0.90 & 0.18 & 9 & 117 & 49 & $<0.8$ & 1016 & 1839 & 379 \\
Velký Blanik & $\mathbf{4 0 7 4}$ & 1.09 & 0.47 & 27 & 48 & 35 & 1.5 & 1218 & 2258 & 756 \\
Velký Blanik & $\mathbf{4 0 7 5}$ & 0.86 & 0.20 & 7 & 104 & 70 & $<0.8$ & 651 & 1676 & 424 \\
Velký Blanik & $\mathbf{4 0 7 6}$ & 1.14 & 0.33 & 4 & 91 & 39 & 1.1 & 1001 & 1800 & 491 \\
Keblov & $\mathbf{3 7 9 6}$ & 1.10 & 0.19 & 6 & 50 & 68 & $<0.8$ & 978 & 1844 & 387 \\
Keblov & $\mathbf{3 7 9 7}$ & 1.07 & 0.25 & 6 & 47 & 68 & $<0.8$ & 1021 & 1870 & 319 \\
Křížov & $\mathbf{3 7 9 9}$ & 1.31 & 0.59 & 3 & 52 & 64 & $<0.8$ & 1077 & 2191 & 451 \\
Javorník & $\mathbf{4 0 7 7}$ & 1.67 & 0.51 & 11 & 83 & 51 & $<0.8$ & 1126 & 2710 & 418 \\
Podmoky & $\mathbf{3 7 7 0}$ & 1.67 & 0.54 & 5 & 29 & 23 & $<0.8$ & 1584 & 3615 & 269 \\
Podmoky & $\mathbf{3 7 7 1}$ & 0.92 & 0.27 & 8 & 26 & 4 & $<0.8$ & 1321 & 2545 & 124 \\
Leština & $\mathbf{3 7 8 7}$ & 0.95 & 0.10 & 6 & 25 & 14 & $<0.8$ & 1026 & 2615 & 368 \\
\hline
\end{tabular}

Fluorapatite

Fluorapatite is the major carrier of phosphorus in biotite orthogneisses. In two-mica and muscovite orthogneisses apatite is also common, but substantial part of phosphorus is hosted in alkali feldspars. All studied apatites are homogeneous fluorapatites without any compositional zoning. Contents of $\mathrm{Cl}, \mathrm{U}, \mathrm{Th}, \mathrm{Sr}$ and $\mathrm{Ba}$ are negligible.
REE contents are low, too - about $0.1-0.2$ wt. $\% \mathrm{Ce}_{2} \mathrm{O}_{3}$ and about $0.1-0.4$ wt. $\% \mathrm{Y}_{2} \mathrm{O}_{3}$, with a slight tendency to enrichment in more peraluminous samples (Table 6).

Fluorapatites from biotite orthogneisses are nearly pure apatites with very low contents of $\mathrm{Mn}$ and $\mathrm{Fe}(<0.1$ apfu), while fluorapatites from two-mica and muscovite orthogneisses are substantially enriched in Mn and slight- 

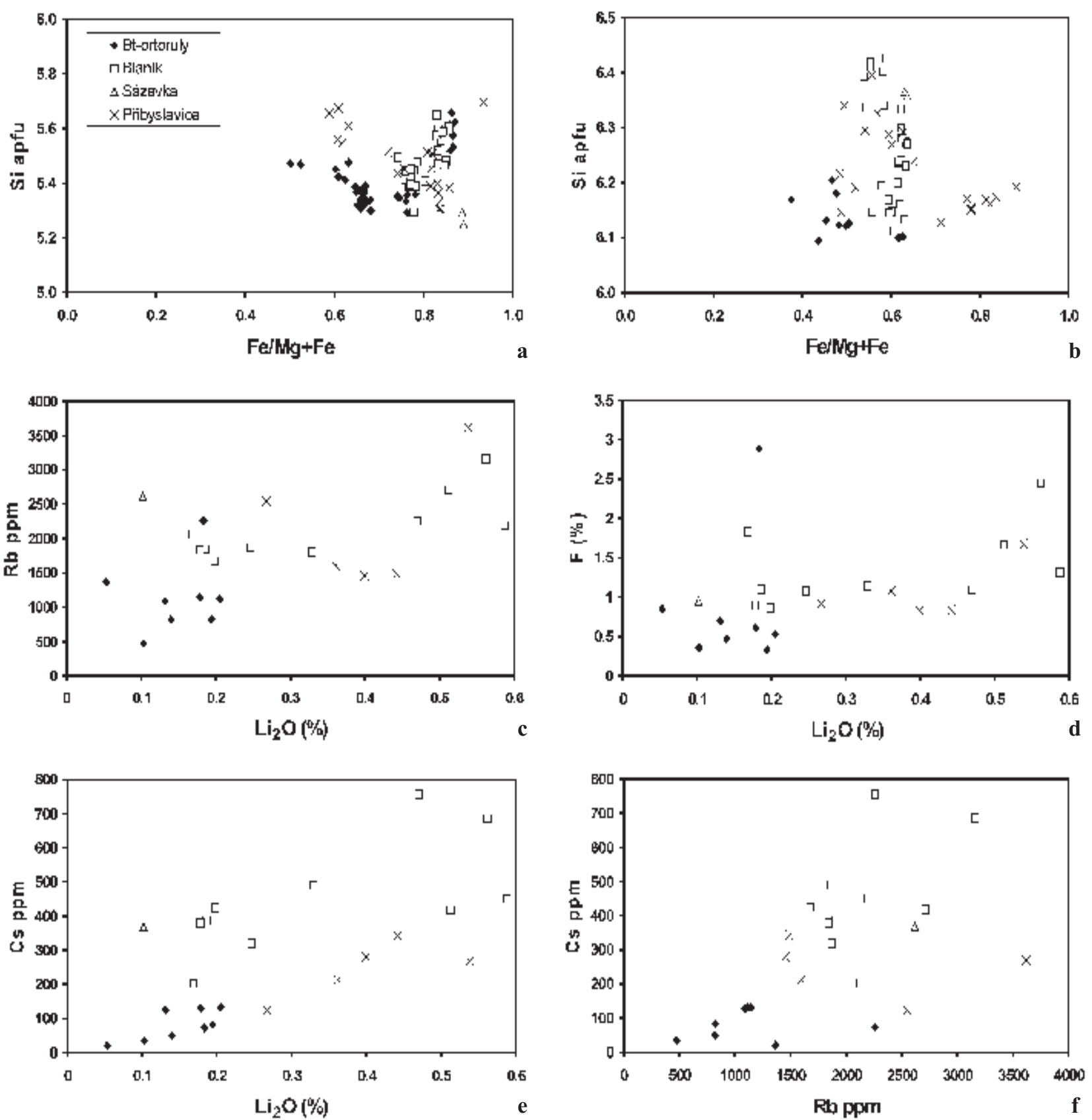

Fig. 5 Chemical composition of micas: a $-\mathrm{Fe} /(\mathrm{Fe}+\mathrm{Mg})$ vs. Si apfu in biotite; $\mathrm{b}-\mathrm{Fe} /(\mathrm{Fe}+\mathrm{Mg})$ vs. Si apfu in muscovite; c $-\mathrm{Li}{ }_{2} \mathrm{O}$ vs. $\mathrm{Rb}$ in biotite; $\mathrm{d}-\mathrm{Li}_{2} \mathrm{O}$ vs. $\mathrm{F}$ in biotite; $\mathrm{e}-\mathrm{Li}_{2} \mathrm{O}$ vs. $\mathrm{Cs}$ in biotite; $\mathrm{f}-\mathrm{Rb}$ vs. Cs in biotite.

ly also in Fe (Fig. 7). The most Mn-rich (0.3-0.6 apfu) apatites were found in tourmaline-bearing orthogneisses.

\section{Zircon}

Zircon is common in biotite and two-mica orthogneisses, but scarce in muscovite and muscovite-tourmaline orthogneisses. Biotite orthogneisses contain simple homogeneous zircon crystals with chemical composition near ideal $\mathrm{ZrSiO}_{4}$. Phosphorus, if present, is compensated by $\mathrm{Y}$, according to xenotime substitution $(\mathrm{Si}+\mathrm{Zr} \leftrightarrow$ $\mathrm{P}+\mathrm{Y}$ ) (Table 7, Fig. 8). Zircons from more fractionated two-mica orthogneisses are more complicated, often zoned and enriched in $\mathrm{P}, \mathrm{U}, \mathrm{Al}, \mathrm{Fe}$ and Sc. In this case, $\mathrm{P}$ in tetrahedral position is coupled with $\mathrm{U}, \mathrm{Fe}$ and $\mathrm{Sc}$ in the $\mathrm{Zr}$-position $[\mathrm{Si}+\mathrm{Zr} \leftrightarrow \mathrm{P}+(\mathrm{U}, \mathrm{Fe}, \mathrm{Sc})]$ and partially also with $\mathrm{Al}$ in tetrahedral position, according to berlinite substitution $2 \mathrm{Si} \leftrightarrow \mathrm{P}+\mathrm{Al}$.

\section{Monazite}

Monazite is a common accessory mineral in all types of biotite and two-mica orthogneisses. With only rare exceptions, all studied monazites are homogeneous without any type of zoning or alteration. Monazite from biotite orthogneisses is Th-, U- and Ca-poor (3.4-8.3 wt. \% $\mathrm{ThO}_{2}$, and uranium usually below 1 wt. $\% \mathrm{UO}_{2}$ ), but with variable Y, also within one thin section (sample from Želiv, Fig. 9a, Table 8). The incorporation of Th and $U$ in the monazite from biotite orthogneisses took place by almost 


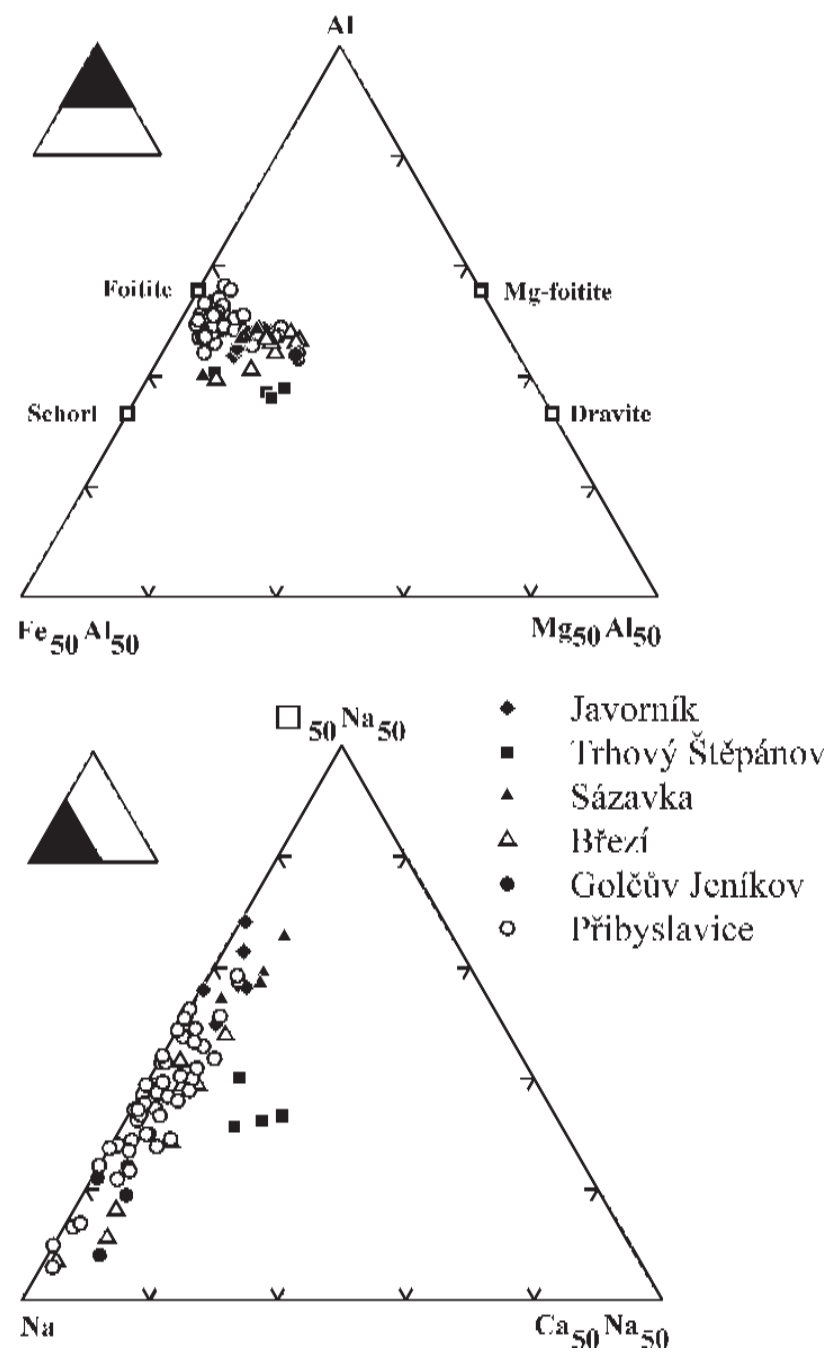

Fig. 6 Tourmaline: upper triangle - totAl-Fe-Mg diagram; lower triangle $-\mathrm{X}$-site occupancy.

pure brabantite substitution (up to $7 \%$ brabantite component) (Fig. 9a).

Monazites from two-mica orthogneisses are more variable, substantially enriched in U (sample from Keblov) or in Th (sample from Mladá Vožice). In Keblov, majority of monazite grains are extremely U-rich (8.4-10.5 wt. \% $\mathrm{UO}_{2}$ ), however, $\mathrm{U}$ enrichment is not accompanied by enrichment in Th (1.0-3.5 wt.\% $\left.\mathrm{ThO}_{2}\right)$. The Th-richer monazite grain (33.9-37.3 wt. \% $\left.\mathrm{ThO}_{2} ; 0.30-0.33 \mathrm{apfu} \mathrm{Th}\right)$ has a composition closer to cheralite-(Ce). Monazite grains from Mladá Vožice sample are rich in Th (11.619.0 wt. \% $\mathrm{ThO}_{2}$ ), with relatively low U (0.6-1.8 wt. \% $\mathrm{UO}_{2}$ ). Th and $\mathrm{U}$ enter the monazite structure dominantly by brabantite substitution (4-14\%), however, huttonite substitution (1-10\%) is also significant. Distribution of chondrite-normalised REE-contents is generally regular with slightly higher content of LREE in monazites from the biotite orthogneisses than from the two-mica orthogneisses. The lowest REE content has been found in Thrich monazite grains from Keblov (Fig. 9b).

Four orthogneiss samples analysed by U-Th-Pb monazite chemical geochronological method yield late
Variscan age of 306-326 Ma (Table 9), which can be attributed to the cooling of Moldanubian crust after Variscan metamorphism.

\section{Ti-oxides}

The whole-rock contents of $\mathrm{Ti}$ are low in biotite orthogneisses (max. 0.3 wt. \% $\mathrm{TiO}_{2}$ ) and even lower in leucocratic orthogneiss $\left(0.05-0.15\right.$ wt. $\left.\% \mathrm{TiO}_{2}\right)$. Majority of $\mathrm{Ti}$ is bound in biotite (2-3 wt. \% $\mathrm{TiO}_{2}$ ), Ti-bearing oxides are scarce. Ilmenite from biotite orthogneisses is typically rich in $\mathrm{Mn}$ (5-9 wt. \% MnO). Rutile from biotite orthogneiss is nearly pure $\mathrm{TiO}_{2}$, but individual grains with up to 1 wt. $\% \mathrm{Nb}_{2} \mathrm{O}_{5}$ and 1.5 wt. $\% \mathrm{Ta}_{2} \mathrm{O}_{5}$ were found in Blaník orthogneiss.

\section{Discussion}

The age of magmatic precursors of tourmaline-muscovite Moldanubian orthogneisses is poorly understood. The only trustworthy age is that published by Vrána and Kröner (1995) from the Hluboká orthogneiss. Six individually evaporated zircon grains yielded ${ }^{207} \mathrm{~Pb} /{ }^{206} \mathrm{~Pb}$ age of $508 \pm 7 \mathrm{Ma}$. Our attempt to use monazite for dating of studied orthogneisses was unsuccessful. All analysed monazite grains yielded a late Variscan age of 316-327 Ma (Table 9), which should be attributed to the lateVariscan metamorphic and post-metamorphic effects (decompression and cooling).

Typical chemical feature of Moldanubian two-mica and muscovite orthogneiss is enrichment in phosphorus $(0.3-$ 0.5 wt. $\left.\% \mathrm{P}_{2} \mathrm{O}_{5}\right)$, tin (30-70 ppm Sn) and tungsten (5-15 ppm W). From this point of view, two-mica orthogneisses are well comparable with peraluminous class of Variscan tin granites through the Bohemian Massif (Breiter 1998). Tin is enriched in both Blaník and Přibyslavice orthogneisses, while tungsten is enriched only in the Blaník orthogneiss. Both elements positively correlate with $\mathrm{F}$ and $\mathrm{P}$ (Fig. 3), which may play an important role in tin transport in late- and/or postmagmatic fluids. However, no indications of tin mineralization within the orthogneisses, nor in surrounding rocks have been found until now. Tin minerals, cassiterite and nigerite, already reported from Přibyslavice (Čech et al. 1978, Povondra et al. 1987) are

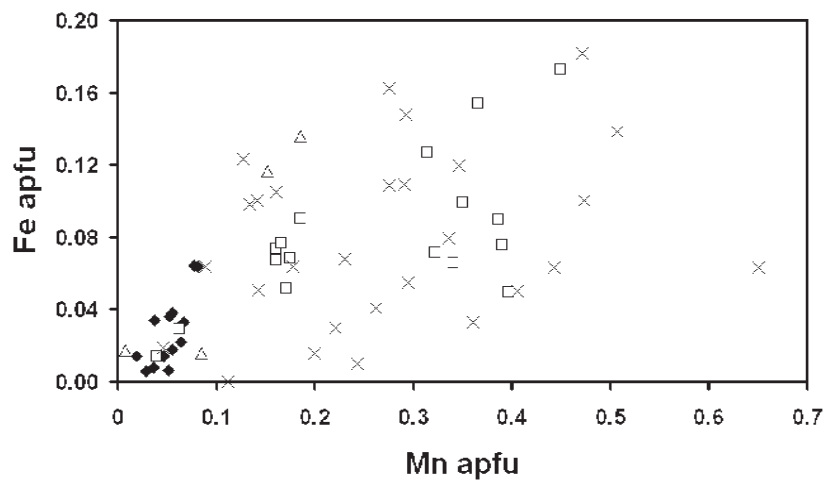

Fig. 7 Contents of Mn and Fe in fluorapatite (atoms per formula unit). 
Table 5 Chemical composition (wt. \%) and empirical formulae (based on 49 positive charges) of tourmaline.

\begin{tabular}{|c|c|c|c|c|c|c|c|c|c|c|c|c|}
\hline $\begin{array}{l}\text { Loca- } \\
\text { lity }\end{array}$ & $\begin{array}{c}\text { Javor- } \\
\text { ník }\end{array}$ & $\begin{array}{c}\text { Javor- } \\
\text { ník }\end{array}$ & $\begin{array}{l}\text { Trhový } \\
\text { Štěpánov }\end{array}$ & $\begin{array}{l}\text { Trhový } \\
\text { Štěpánov }\end{array}$ & $\begin{array}{c}\text { Sázav- } \\
\text { ka }\end{array}$ & $\begin{array}{c}\text { Sázav- } \\
\text { ka }\end{array}$ & Březí & Březí & $\begin{array}{l}\text { Přibys- } \\
\text { lavice }\end{array}$ & $\begin{array}{l}\text { Přibys- } \\
\text { lavice }\end{array}$ & $\begin{array}{l}\text { Přibys- } \\
\text { lavice }\end{array}$ & $\begin{array}{l}\text { Pribys- } \\
\text { lavice }\end{array}$ \\
\hline No. & 4077 & 4077 & 3798 & 3798 & 3485 & 3485 & 3267 & 3266 & 3283 & 3283 & 3270 & 3270 \\
\hline $\mathrm{SiO}_{2}$ & 35.02 & 35.98 & 35.45 & 35.33 & 34.95 & 34.56 & 35.25 & 34.88 & 35.33 & 35.14 & 35.19 & 33.97 \\
\hline $\mathrm{TiO}_{2}$ & 0.84 & 1.00 & 0.33 & 0.72 & 0.68 & 1.12 & 0.93 & 0.74 & 0.27 & 1.02 & 0.49 & 0.66 \\
\hline $\mathrm{Al}_{2} \mathrm{O}_{3}$ & 32.99 & 31.46 & 30.80 & 30.46 & 32.94 & 32.97 & 32.96 & 32.09 & 33.17 & 33.15 & 32.59 & 33.93 \\
\hline $\mathrm{FeO}$ & 12.70 & 13.10 & 15.19 & 12.40 & 13.00 & 13.41 & 10.46 & 13.88 & 14.98 & 11.40 & 14.84 & 13.10 \\
\hline MnO & 0.19 & 0.00 & 0.02 & 0.03 & 0.10 & 0.18 & 0.00 & 0.28 & 0.00 & 0.20 & 0.25 & 0.00 \\
\hline MgO & 2.05 & 1.91 & 1.71 & 3.91 & 2.03 & 1.97 & 3.64 & 2.77 & 0.49 & 2.98 & 0.93 & 2.00 \\
\hline $\mathrm{CaO}$ & 0.15 & 0.02 & 0.37 & 0.65 & 0.11 & 0.23 & 0.25 & 0.12 & 0.00 & 0.15 & 0.00 & 0.03 \\
\hline $\mathrm{Na}_{2} \mathrm{O}$ & 2.09 & 1.95 & 2.16 & 2.13 & 2.14 & 1.91 & 2.52 & 2.57 & 2.20 & 2.22 & 2.37 & 2.51 \\
\hline $\mathbf{K}_{2} \mathbf{O}$ & 0.05 & 0.11 & 0.10 & 0.09 & 0.06 & 0.06 & 0.00 & 0.15 & 0.11 & 0.00 & 0.17 & 0.02 \\
\hline Total & 86.09 & 85.61 & 86.14 & 85.70 & 86.04 & 86.40 & 86.18 & 87.49 & 86.56 & 86.32 & 86.83 & 86.22 \\
\hline $\mathbf{S i}$ & 5.889 & 6.083 & 6.045 & 5.985 & 5.889 & 5.818 & 5.859 & 5.840 & 5.962 & 5.856 & 5.940 & 5.726 \\
\hline $\mathbf{T i}$ & 0.106 & 0.128 & 0.042 & 0.092 & 0.086 & 0.141 & 0.116 & 0.093 & 0.034 & 0.128 & 0.063 & 0.083 \\
\hline Al & 6.537 & 6.269 & 6.190 & 6.081 & 6.544 & 6.543 & 6.456 & 6.335 & 6.598 & 6.511 & 6.483 & 6.742 \\
\hline $\mathrm{Fe}$ & 1.785 & 1.853 & 2.166 & 1.756 & 1.833 & 1.888 & 1.454 & 1.944 & 2.115 & 1.589 & 2.095 & 1.847 \\
\hline Mn & 0.026 & 0.000 & 0.002 & 0.005 & 0.014 & 0.026 & 0.000 & 0.040 & 0.000 & 0.029 & 0.035 & 0.000 \\
\hline Mg & 0.514 & 0.482 & 0.435 & 0.987 & 0.510 & 0.494 & 0.903 & 0.693 & 0.124 & 0.739 & 0.235 & 0.503 \\
\hline $\mathrm{Ca}$ & 0.028 & 0.004 & 0.068 & 0.118 & 0.019 & 0.041 & 0.044 & 0.022 & 0.000 & 0.026 & 0.000 & 0.005 \\
\hline $\mathbf{N a}$ & 0.683 & 0.640 & 0.714 & 0.698 & 0.699 & 0.624 & 0.812 & 0.835 & 0.721 & 0.717 & 0.774 & 0.820 \\
\hline
\end{tabular}

Table 6 Chemical composition (wt. \%) and empirical formulae (based on 25 positive charges) of apatite.

\begin{tabular}{|c|c|c|c|c|c|c|c|c|c|c|}
\hline Locality & Želiv & Cetoraz & Mladá Vožice & Keblov & Blaník & Javornik & Přibyslavice & Přibyslavice & Přibyslavice & Přibyslavice \\
\hline No. & 4080 & 4069 & 4072 & 3796 & 4076 & 4077 & 3262 & 3282 & $3674 b$ & $3674 a$ \\
\hline $\mathrm{SiO}_{2}$ & & & & & & & 0.00 & 0.09 & 0.09 & 0.11 \\
\hline $\mathrm{TiO}_{2}$ & & & & & & & 0.16 & 0.00 & 0.04 & 0.00 \\
\hline $\mathrm{Al}_{2} \mathrm{O}_{3}$ & & & & & & & 0.00 & 0.00 & 0.11 & 0.17 \\
\hline $\mathrm{FeO}$ & 0.11 & 0.20 & 0.20 & 1.07 & 1.00 & 2.41 & 1.93 & 1.54 & 0.43 & 0.47 \\
\hline MnO & 0.51 & 0.65 & 0.55 & 2.27 & 4.45 & 6.18 & 6.97 & 3.86 & 3.11 & 5.12 \\
\hline MgO & & & & & & & 0.00 & 0.06 & 0.00 & 0.00 \\
\hline $\mathrm{CaO}$ & 54.83 & 54.34 & 54.46 & 51.54 & 50.50 & 47.24 & 45.89 & 49.52 & 50.72 & 49.15 \\
\hline $\mathrm{Na}_{2} \mathrm{O}$ & 0.12 & 0.10 & 0.25 & 0.23 & 0.12 & 0.20 & 0.33 & 0.27 & 0.08 & 0.00 \\
\hline $\mathrm{K}_{2} \mathrm{O}$ & & & & & & & 0.01 & 0.00 & 0.00 & 0.14 \\
\hline $\mathrm{P}_{2} \mathrm{O}_{5}$ & 41.28 & 41.30 & 41.89 & 41.29 & 41.25 & 41.37 & 41.67 & 42.66 & 43.13 & 43.57 \\
\hline Total & 100.95 & 100.87 & 102.31 & 100.48 & 101.29 & 101.13 & 96.96 & 98.00 & 97.70 & 98.73 \\
\hline $\mathbf{S i}$ & & & & & & & 0.000 & 0.008 & 0.008 & 0.009 \\
\hline $\mathbf{T i}$ & & & & & & & 0.011 & 0.000 & 0.002 & 0.000 \\
\hline Al & & & & & & & 0.000 & 0.000 & 0.011 & 0.017 \\
\hline $\mathrm{Fe}$ & 0.008 & 0.014 & 0.014 & 0.077 & 0.072 & 0.173 & 0.138 & 0.109 & 0.030 & 0.033 \\
\hline Mn & 0.037 & 0.047 & 0.039 & 0.165 & 0.322 & 0.449 & 0.507 & 0.275 & 0.221 & 0.361 \\
\hline Mg & & & & & & & 0.001 & 0.007 & 0.000 & 0.000 \\
\hline $\mathrm{Ca}$ & 5.004 & 4.969 & 4.932 & 4.739 & 4.628 & 4.345 & 4.225 & 4.468 & 4.555 & 4.382 \\
\hline $\mathrm{Na}$ & 0.020 & 0.017 & 0.041 & 0.038 & 0.020 & 0.033 & 0.055 & 0.044 & 0.013 & 0.000 \\
\hline K & & & & & & & 0.001 & 0.000 & 0.000 & 0.014 \\
\hline $\mathbf{P}$ & 2.977 & 2.984 & 2.998 & 3.000 & 2.987 & 3.006 & 3.032 & 3.041 & 3.061 & 3.070 \\
\hline
\end{tabular}

genetically linked to small intrusion of Variscan highly fractionated granite intruding into orthogneiss body (Breiter and Škoda, in press). Small tungsten mineralization found in quartz stockwork at Cetoraz (Němec and Tenčík, 1976, Němec and Páša, 1986) was interpreted as metamorphosed pre-Variscan greisen and attributed genetically to the Cetoraz orthogneiss. According to our chemical data, the Cetoraz-Pacov orthogneiss is poor in tungsten (2-4 ppm $\mathrm{W}$ ) and this interpretation seams to be problematic.
In contrast to the above mentioned general similarity between leucocratic orthogneisses and Variscan tin granites, enrichment in boron, represented macroscopically by tourmaline, is a specific feature only of the orthogneiss (Čadková et al. 1984). We found no correlation between boron and tin, therefore boron does not play a significant role in tin transport and enrichment.

High content of Al, P, B together with low content of $\mathrm{Ca}$ in leucocratic orthogneisses is compatible with their 

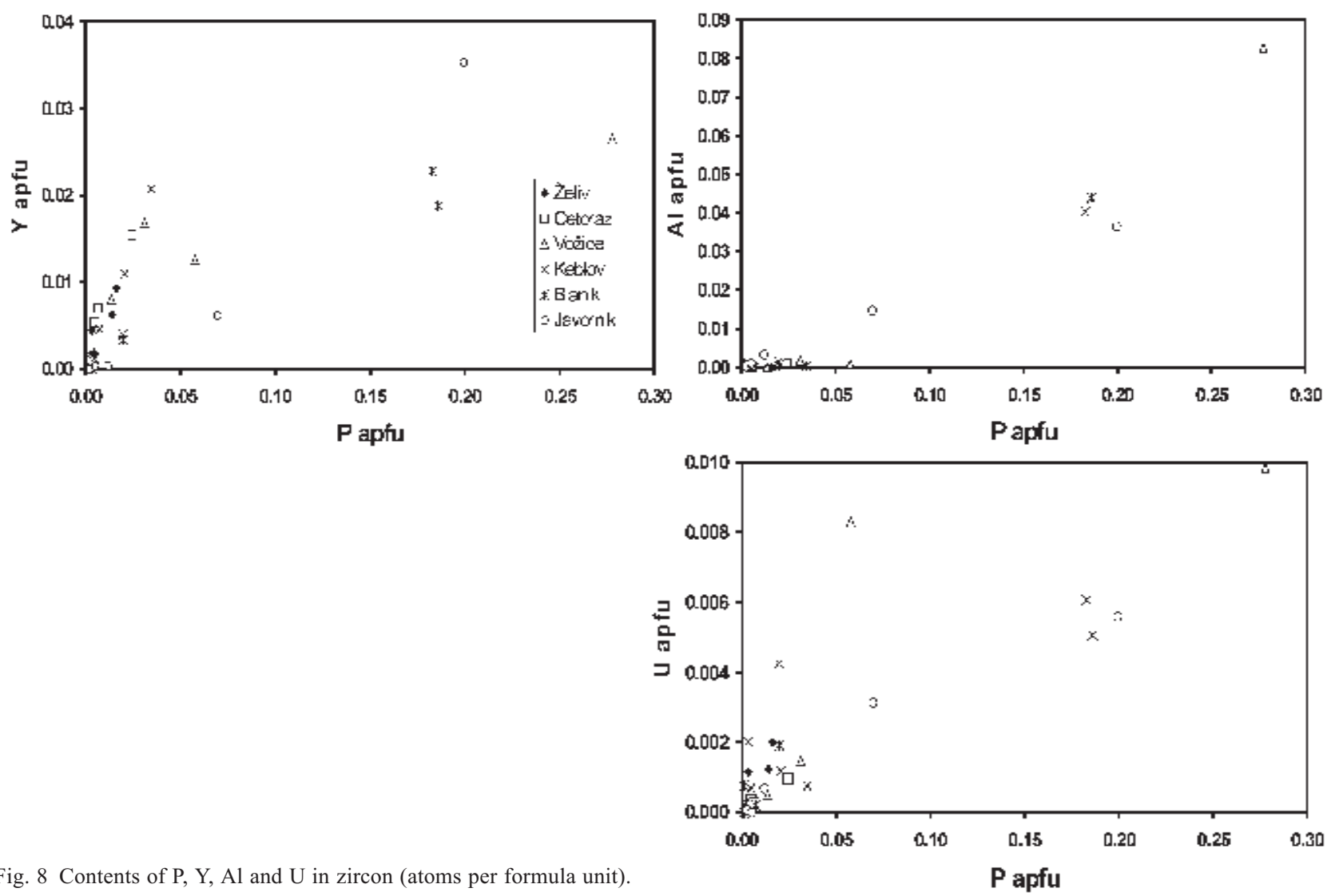

Fig. 8 Contents of $\mathrm{P}, \mathrm{Y}, \mathrm{Al}$ and $\mathrm{U}$ in zircon (atoms per formula unit).

Table 7 Chemical composition (wt. \%) and empirical formulae (based on 8 positive charges) of zircon.

\begin{tabular}{|c|c|c|c|c|c|c|c|c|}
\hline Locality & Želiv & Cetoraz & Mladá Vožice & Mladá Vožice & Velký Blaník & Velký Blaník & Velký Blaník & Velký Blaník \\
\hline No. & 4080 & 4069 & 4072 & 4072 & 4076 & 4076 & 4077 & 4077 \\
\hline $\mathrm{SiO}_{2}$ & 32.37 & 31.64 & 31.27 & 18.93 & 24.16 & 32.31 & 31.50 & 21.04 \\
\hline $\mathrm{ZrO}_{2}$ & 65.97 & 64.15 & 64.79 & 53.91 & 57.73 & 64.90 & 64.35 & 54.50 \\
\hline $\mathrm{HfO}_{2}$ & 0.98 & 1.15 & 1.29 & 1.88 & 2.00 & 2.24 & 2.23 & 1.79 \\
\hline $\mathrm{Al}_{2} \mathrm{O}_{3}$ & 0.01 & 0.00 & 0.00 & 2.03 & 1.16 & 0.02 & 0.09 & 0.91 \\
\hline $\mathbf{P}_{2} \mathbf{O}_{5}$ & 0.18 & 0.24 & 0.51 & 9.50 & 6.84 & 0.04 & 0.45 & 6.92 \\
\hline $\mathrm{CaO}$ & 0.03 & 0.03 & 0.00 & 0.90 & 1.33 & 0.01 & 0.06 & 2.24 \\
\hline $\mathrm{ThO}_{2}$ & 0.05 & 0.12 & 0.00 & 0.13 & 0.01 & 0.00 & 0.00 & 0.05 \\
\hline $\mathbf{U O}_{2}$ & 0.05 & 0.04 & 0.07 & 1.28 & 0.71 & 0.00 & 0.10 & 0.74 \\
\hline $\mathrm{FeO}$ & 0.12 & 0.39 & 0.00 & 1.32 & 1.26 & 0.01 & 0.14 & 1.21 \\
\hline MnO & 0.00 & 0.02 & 0.00 & 0.05 & 0.09 & 0.02 & 0.02 & 0.07 \\
\hline $\mathbf{Y}_{2} \mathrm{O}_{3}$ & 0.11 & 0.42 & 0.48 & 1.44 & 1.10 & 0.00 & 0.02 & 1.95 \\
\hline $\mathrm{Yb}_{2} \mathrm{O}_{3}$ & 0.05 & 0.13 & 0.17 & 0.39 & 0.31 & 0.01 & 0.00 & 0.51 \\
\hline $\mathrm{Sc}_{2} \mathrm{O}_{3}$ & 0.04 & 0.04 & 0.03 & 0.14 & 0.30 & 0.03 & 0.07 & 0.77 \\
\hline $\mathbf{F}$ & 0.00 & 0.00 & 0.00 & 1.01 & 0.82 & 0.00 & 0.01 & 0.96 \\
\hline Total & 99.95 & 98.37 & 98.61 & 92.90 & 97.82 & 99.60 & 99.03 & 93.65 \\
\hline Si & 0.993 & 0.989 & 0.977 & 0.653 & 0.776 & 0.999 & 0.982 & 0.716 \\
\hline $\mathbf{Z r}$ & 0.987 & 0.978 & 0.987 & 0.908 & 0.904 & 0.979 & 0.978 & 0.905 \\
\hline Hf & 0.009 & 0.010 & 0.012 & 0.019 & 0.018 & 0.020 & 0.020 & 0.017 \\
\hline Al & 0.000 & 0.000 & 0.000 & 0.083 & 0.044 & 0.001 & 0.003 & 0.037 \\
\hline $\mathbf{P}$ & 0.005 & 0.006 & 0.013 & 0.278 & 0.186 & 0.001 & 0.012 & 0.199 \\
\hline $\mathrm{Ca}$ & 0.001 & 0.001 & 0.000 & 0.033 & 0.046 & 0.000 & 0.002 & 0.082 \\
\hline Th & 0.000 & 0.001 & 0.000 & 0.001 & 0.000 & 0.000 & 0.000 & 0.000 \\
\hline $\mathbf{U}$ & 0.000 & 0.000 & 0.000 & 0.010 & 0.005 & 0.000 & 0.001 & 0.006 \\
\hline $\mathrm{Fe}$ & 0.003 & 0.010 & 0.000 & 0.038 & 0.034 & 0.000 & 0.004 & 0.034 \\
\hline Mn & 0.000 & 0.001 & 0.000 & 0.001 & 0.002 & 0.001 & 0.001 & 0.002 \\
\hline $\mathbf{Y}$ & 0.002 & 0.007 & 0.008 & 0.026 & 0.019 & 0.000 & 0.000 & 0.035 \\
\hline $\mathbf{Y b}$ & 0.000 & 0.001 & 0.002 & 0.004 & 0.003 & 0.000 & 0.000 & 0.005 \\
\hline Sc & 0.001 & 0.001 & 0.001 & 0.004 & 0.008 & 0.001 & 0.002 & 0.023 \\
\hline $\mathbf{F}$ & 0.000 & 0.000 & 0.000 & 0.110 & 0.083 & 0.000 & 0.001 & 0.103 \\
\hline
\end{tabular}


Table 8 Chemical composition (wt. \%) and empirical formulae (based on 8 positive charges) of monazite.

\begin{tabular}{|c|c|c|c|c|c|c|c|c|}
\hline Locality & Cetoraz & Cetoraz & Želiv & Želiv & Vožice & Vožice & Keblov & Keblov \\
\hline No. & 4069 & 4069 & 4080 & 4080 & 4072 & 4072 & 3796 & 3796 \\
\hline $\mathrm{P}_{2} \mathrm{O}_{5}$ & 30.08 & 29.11 & 30.03 & 29.90 & 29.78 & 28.60 & 29.94 & 28.68 \\
\hline $\mathrm{SiO}_{2}$ & 0.20 & 0.63 & 0.16 & 0.19 & 0.46 & 1.07 & 0.15 & 0.85 \\
\hline $\mathrm{UO}_{2}$ & 2.27 & 0.54 & 1.34 & 0.71 & 1.65 & 1.34 & 9.05 & 3.26 \\
\hline $\mathrm{ThO}_{2}$ & 5.04 & 6.07 & 6.54 & 3.41 & 13.38 & 19.05 & 1.23 & 37.28 \\
\hline $\mathrm{Al}_{2} \mathrm{O}_{3}$ & 0.00 & 0.01 & 0.01 & 0.00 & 0.00 & 0.00 & 0.00 & 0.02 \\
\hline $\mathrm{La}_{2} \mathrm{O}_{3}$ & 12.88 & 13.98 & 12.38 & 13.53 & 11.55 & 11.26 & 11.54 & 7.34 \\
\hline $\mathrm{Ce}_{2} \mathrm{O}_{3}$ & 27.12 & 27.94 & 26.71 & 28.52 & 24.51 & 22.32 & 25.38 & 10.94 \\
\hline $\mathrm{Pr}_{2} \mathrm{O}_{3}$ & 2.96 & 2.93 & 2.93 & 3.10 & 2.45 & 2.11 & 2.72 & 0.92 \\
\hline $\mathrm{Nd}_{2} \mathrm{O}_{3}$ & 10.55 & 10.03 & 10.45 & 11.95 & 7.64 & 6.35 & 9.43 & 2.72 \\
\hline $\mathrm{Sm}_{2} \mathrm{O}_{3}$ & 2.18 & 2.02 & 2.56 & 2.51 & 1.50 & 1.20 & 1.92 & 0.44 \\
\hline $\mathrm{Gd}_{2} \mathrm{O}_{3}$ & 1.55 & 1.39 & 1.80 & 1.75 & 0.99 & 0.82 & 1.45 & 0.22 \\
\hline $\mathrm{Dy}_{2} \mathrm{O}_{3}$ & 0.74 & 0.69 & 0.74 & 0.59 & 0.66 & 0.57 & 0.76 & 0.06 \\
\hline $\mathrm{Er}_{2} \mathrm{O}_{3}$ & 0.15 & 0.14 & 0.15 & 0.10 & 0.18 & 0.16 & 0.17 & 0.03 \\
\hline $\mathrm{Y}_{2} \mathrm{O}_{3}$ & 2.25 & 2.18 & 2.25 & 1.69 & 2.30 & 2.03 & 2.52 & 0.28 \\
\hline PbO & 0.19 & 0.12 & 0.16 & 0.09 & 0.28 & 0.33 & 0.44 & 0.68 \\
\hline $\mathrm{CaO}$ & 1.47 & 0.87 & 1.63 & 0.80 & 2.79 & 3.28 & 2.22 & 7.75 \\
\hline Total & 99.61 & 98.64 & 99.82 & 98.84 & 100.13 & 100.47 & 98.91 & 101.48 \\
\hline $\mathbf{P}$ & 0.995 & 0.978 & 0.993 & 0.998 & 0.983 & 0.954 & 0.996 & 0.952 \\
\hline Si & 0.008 & 0.025 & 0.006 & 0.007 & 0.018 & 0.042 & 0.006 & 0.033 \\
\hline $\mathbf{U}$ & 0.020 & 0.005 & 0.012 & 0.006 & 0.014 & 0.012 & 0.079 & 0.028 \\
\hline Th & 0.045 & 0.055 & 0.058 & 0.031 & 0.119 & 0.171 & 0.011 & 0.333 \\
\hline Al & 0.000 & 0.000 & 0.000 & 0.000 & 0.000 & 0.000 & 0.000 & 0.001 \\
\hline La & 0.186 & 0.205 & 0.178 & 0.197 & 0.166 & 0.163 & 0.167 & 0.106 \\
\hline $\mathrm{Ce}$ & 0.388 & 0.406 & 0.382 & 0.412 & 0.350 & 0.322 & 0.365 & 0.157 \\
\hline Pr & 0.042 & 0.042 & 0.042 & 0.045 & 0.035 & 0.030 & 0.039 & 0.013 \\
\hline Nd & 0.147 & 0.142 & 0.146 & 0.168 & 0.106 & 0.089 & 0.132 & 0.038 \\
\hline Sm & 0.029 & 0.028 & 0.034 & 0.034 & 0.020 & 0.016 & 0.026 & 0.006 \\
\hline Gd & 0.020 & 0.018 & 0.023 & 0.023 & 0.013 & 0.011 & 0.019 & 0.003 \\
\hline Dy & 0.009 & 0.009 & 0.009 & 0.008 & 0.008 & 0.007 & 0.010 & 0.001 \\
\hline Er & 0.002 & 0.002 & 0.002 & 0.001 & 0.002 & 0.002 & 0.002 & 0.000 \\
\hline $\mathbf{Y}$ & 0.047 & 0.046 & 0.047 & 0.035 & 0.048 & 0.043 & 0.053 & 0.006 \\
\hline $\mathbf{P b}$ & 0.002 & 0.001 & 0.002 & 0.001 & 0.003 & 0.003 & 0.005 & 0.007 \\
\hline $\mathbf{C a}$ & 0.062 & 0.037 & 0.068 & 0.034 & 0.116 & 0.138 & 0.093 & 0.326 \\
\hline
\end{tabular}

Table 9 Age of monazite analysed by U-Th-Pb method.

\begin{tabular}{|l|l|l|}
\hline Locality & Rock & Age of monazite \\
\hline Želiv & Biotite orthogneiss & $306 \pm 19 \mathrm{Ma}$ \\
Cetoraz & Biotite orthogneiss & $318 \pm 25 \mathrm{Ma}$ \\
Mlada Vožice-Šelmberk & Two-mica orthogneiss & $319 \pm 15 \mathrm{Ma}$ \\
Keblov & Two-mica orthogneiss & $326.6 \pm 9.9 \mathrm{Ma}$ \\
& with garnet & \\
\hline
\end{tabular}

source in (meta-)pelitic rocks. Near-minimum melting based on breakdown of muscovite may have enriched primary melt particularly in B and Sn. Later behaviour of tin during fractionation was more influenced by concentration of fluorine.

Studied Blaník-type orthogneisses can be well correlated with the Hluboká and Radonice orthogneisses from the southern part of Moldanubicum (Slabý 1991). Povondra and Vrána (1996) stressed relatively more magnesian composition of the Radonice orthogneiss $\left(\mathrm{MgO} / \mathrm{FeO}_{\text {tot }}\right.$ about 0.2) in comparison to the Hluboká orthogneiss $\left(\mathrm{MgO} / \mathrm{FeO}_{\text {tot }}\right.$ about 0.1$)$, but similar differences in $\mathrm{Mg}$ /
Fe ratio can be found also within the Blaník orthogneisses. The bodies at Keblov and Trhový Štěpánov are from this point of view similar to Radonice orthogneiss, the other bodies are similar to the Hluboká orthogneiss $\left(\mathrm{MgO} / \mathrm{FeO}_{\text {tot }}<0.1\right)$.

Studied biotite orthogneisses are in all aspects well comparable with biotite orthogneisses from the southwestern part of the Moldanubicum (Bechyně and Nové Hrady, Slabý 1991).

Figs $5 \mathrm{a}$ and $5 \mathrm{~b}$ compare $\mathrm{Si}, \mathrm{Fe}$ and $\mathrm{Mg}$ contents in coexisting biotite-muscovite pairs. In biotite orthogneisses, both biotite and muscovite are relatively close to ideal annite, resp. muscovite compositions. In more evolved leucocratic and more silicic rocks, biotite is depleted in $\mathrm{Fe}+\mathrm{Mg}$ (and $\mathrm{Si}+\mathrm{Al}$-enriched), while muscovite is substantially Fe, Mg-enriched. There are, unfortunately, no sufficient criteria for interpretation of the relative roles of magmatic or metamorphic processes in this resulting pattern.

Němec (1980) studied phengitic muscovite from the orthogneisses in Moldanubicum (Blaník and Přibyslav- 

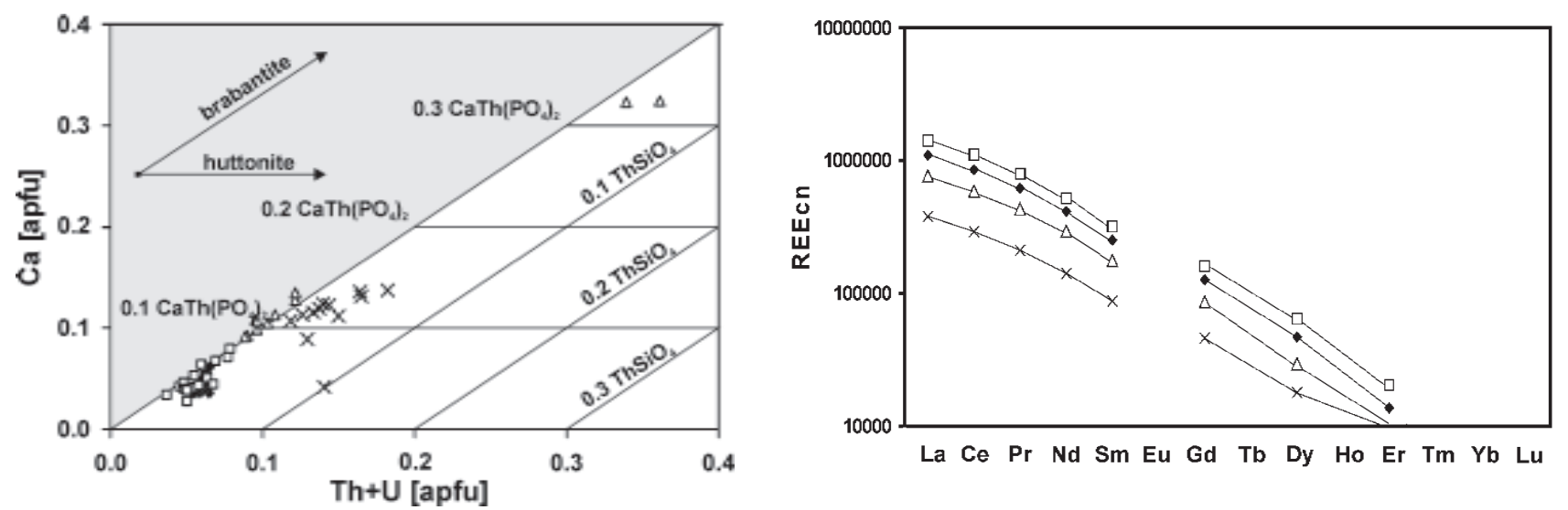

Fig. 9 Monazite: left - brabantite and huttonite substitution; right - chondrite-normalised REE distribution.

ice) and in the Svratka anticline. He found 0.24-0.59 apfu $\mathrm{Fe}+\mathrm{Mn}+\mathrm{Mg}$ and $0.5-2.5$ wt. \% F. According to our data, the Blaník orthogneisses contain muscovite with $0.25-$ 0.55 apfu (occasionally $0.80 \mathrm{apfu}) \mathrm{Fe}+\mathrm{Mg}$ and $0.5-1.5$ wt. \% F, which is generally well comparable.

Fluorapatites from the Prribyslavice and Blaník orthogneiss preserve their primary magmatic composition, as follows from a close compositional similarity to primary fluorapatites in tourmaline pegmatites and alkali-feldspar granites from worldwide localities. Fluorapatites from biotite orthogneisses differ significantly by being much closer in their composition to ideal Ca-phosphate. The former have a composition comparable with fluorapatite from Hluboká (2.11-2.84 wt. \% MnO, 0.86-2.38 wt. \% FeO and 2.88-3.18 wt. \% F), which was together with tourmaline interpreted as a primary magmatic phase by Povondra and Vrána $(1993,1996)$. The Mn- and Fe-content in fluorapatite is significant in the context of fractionation of the magmatic precursors of orthogneisses, which was, of course, much higher in the case of the two-mica and tourmalinebearing orthogneisses than in biotite orthogneisses.

The monazite structure prefers Th to $\mathrm{U}$, and concentration of $\mathrm{UO}_{2}$ in monazite from granitic rocks rarely exceeds 2.5 wt. $\% \mathrm{UO}_{2}$. Concentration of $\mathrm{U}$ in monazite from Keblov ranges from 8.4 to 10.5 wt. \% $\mathrm{UO}_{2}$. Such high $\mathrm{U}$ content is known in monazite from U-rich leucogranite from Albuquerque, Spain, which contains up to 13.8 wt. $\% \mathrm{UO}_{2}$ (Bea 1996), or from several granitic pegmatites contaning 9.5 wt. \% $\mathrm{UO}_{2}$ (Gulson and Krogh 1973 ) and $~ 15.6$ wt. \% UO $($ Gramaccioli and Segelstad 1978). Uranium-enriched and Th-depleted monazites from Keblov yield an extreme $\mathrm{Th} / \mathrm{U}$ ratio in the range of $0.1-0.3$. In the typical monazite the $\mathrm{Th} / \mathrm{U}$ ratio is higher or equal to 10 ; monazites from peraluminous granites of the Erzgebirge-Fichtelgebirge region, Germany, show Th/U ratios close to or below 1 (Förster 1998). Podor et al. (1995), based on the experimental work, found no crystal-chemical limit to entry of $U$ in the monazite structure and supposed influence of $U$ and Th content in the melt on the $\mathrm{Th} / \mathrm{U}$ ratio in monazites. On the other hand, U-rich melts are likely to produce monazite with predominance of $\mathrm{Th}$ over $\mathrm{U}$ and uraninite and uranothorite
(Förster 1998). Pan (1997) described simultaneous formation of Th-poor and Th-rich monazite in gneisses by breakdown of pre-existing REE- and Th- rich minerals (titanite, zircon). The sample from Keblov has a low whole-rock concentration of $\mathrm{U}$ and $\mathrm{Th}$, similar to the other two-mica or muscovite-tourmaline orthogneisses.

\section{Conclusions}

Our attempt to use monazite to determine age of magmatic precursor of orthogneisses was unsuccessful. Nevertheless, from the whole-rock chemistry and similarities in mineral composition we can conclude that all the studied rocks are probably products of one extensive lower Palaeozoic magmatic event, which was important in the northeastern part of Moldanubicum. This magmatic event was characterised by peraluminous melts, with sources probably dominated by metasedimentary formations in a deeper level of Moldanubicum. Near-minimum melting involving muscovite enriched the primary melts in boron. Following fractionation led to enrichment in phosphorus and tin. The most fractionated rocks of this event form a discontinuous belt between the Blaník hill in the SW and Pribyslavice in the NE at the present denudation level.

Acknowledgement. This paper was produced within the frame of internal project of Czech Geological Survey No. 3228 "Lithology of the NE Moldanubicum and adjacent areas". Detailed reviews by S. Vrána and J. Leichman helped to improve the manuscript significantly and are cordially acknowledged.

Submitted March 28, 2006

\section{References}

Bea, F. (1996): Residence of REE, Y, Th and U in granites and crustal protoliths; Implications for the chemistry of crustal melts. - Journal of Petrology, 37, 521-552.

Beneš, K. (1963): Vysvětlivky k přehledné geologické mapě ČSSR 1:200 000, list M-33-XXII Jihlava. 200 p. ÚÚG Praha.

Breiter, K. (ed., 1998): Genetic significance of phosphorus in fractionated granites. -170 p. CGS Praha. 
Breiter, K. - Beran, A. - Buriánek, D. - Cempírek, J. - Dutrow, B. Henry, D. - Novák, M. - Raimboult, L. (2003): Přibyslavice near Ćáslav, tourmaline-muscovite orthogneiss, muscovite grante, pegmatite. In: Novák, M. (ed): International symposium on light elements in rock forming minerals LERM 2003, Field trip guidebook, 77-90. Masaryk University Brno.

Breiter, K. - Förster, H.-J. - Škoda, R. (in press): Extreme P-, Bi-, Nb-, Sc-, U- and F-rich zircon from fractionated perphosphorus granites. Lithos.

Breiter, K. - Koller, F. (1999): Two-mica granites in the central part of the South Bohemian Pluton. Abh. Geol. B.-A., 56, 201-212. Wien.

Breiter, K. - Scharbert, S. (1998): Latest intrusions of the Eisgarn pluton (South Bohemia - Northern Waldviertel). - Jb. Geol. B.-A., 141, 2537. Wien.

Breiter, K. - Sulovský, P. (2005): Geochronology of the Melechov massif. - Geoscience Research Reports for 2004, 16-19. C̆GS Praha. (in Czech with English resume)

Breiter, $K$. - Škoda, $R$. (in press): Tin, niobium and tantalum mineralization at Přibyslavice near Ćáslav. - Geoscience Research Reports for 2005, ČGS Praha. (in Czech with English resume)

Čadková, Z. et al. (1984): Katalog analys regionální geochemické sítě. MS Ústřední ústav geologický Praha.

Förster, H. J. (1998): The chemical composition of REE-Y-Th-U-rich accessory minerals in peraluminous granites of the ErzgebirgeFichtelgebirge region, Germany, Part I: The monazite-(Ce)-brabantite solid solution series. - Amer. Mineralogist, 83, 259-272.

Gramaccioli, C. M. - Segalstad, T. V. (1978): A uranium- and thorium rich monazite from a south-alpine pegmatite at Piona, Italy. - Amer. Mineralogist, 63, 757-761.

Gulson, B. L. - Krogh, T. E. (1973): Old lead component in the young Bergell Massif, south-east Swiss Alps. - Contrib. Mineral. Petrol., 40, 239-252.

Klečka, M. - Machart, J. - Pivec, E. (1992): Locality No. 10: Křížovská hora quarry near Vlašim. In: Novák, M. - Černý, P. (eds): Lepidolite 200. Field trip guidebook. 69-74. MU and MM Brno.

Kodym, O. et al. (1963): Vysvětlivky k přehledné geologické mapě ČSSR 1:200 000, list M-33-XXI Tábor. 232 p. ÚÚG Praha.

- (1967): Geological map of ČSSR 1:500 000. Ústřední ústav geologický Praha.
Němec, D. (1980): Fluorine phengites from tin-bearing orthogneisses of the Bohemian-Moravian Heights, Czechoslovakia. - N. Jb. Miner. Abh., 139, 155-169.

Němec, D. - Páša, J. (1986): Regionally metamorphosed greisens of the Moldanubicum. - Min. Deposita, 21, 12-21.

Němec, D. - Tenčík, I. (1976): Regionally metamorphosed greisens at Cetoraz, the Bohemian-Moravian Heights (Českomoravská vrchovina), Czechoslovakia. - Min. Deposita, 11, 210-217.

Pan, Y. (1997): Zircon- and monazite-forming metamorphic reactions at Manitouwadge, Ontario. - Canad. Mineralogist, 35, 105-118.

Podor, R. - Cuney, M. - Nguyen T. C. (1995): Experimental study of the solid solution between monazite-(La) and $\left(\mathrm{Ca}_{0.5} \mathrm{U}_{0.5}\right) \mathrm{PO}_{4}$ at $780{ }^{\circ} \mathrm{C}$ and $200 \mathrm{MPa}$. - Amer. Mineralogist, 80, 1261-1268.

Povondra, P. - Pivec, E. - Čech, F. - Lang, M. - Novák, F. - Prachař, I. Ulrych, J. (1987): Přibyslavice peraluminous granite. - Acta Univ. Carol. Geol., 183-283.

Povondra, P. - Vrána, S. (1993): Crystal chemistry of apatite in tourmaline-bearing alkali-feldspar orthogneiss near Hluboká nad Vltavou, southern Bohemia. Journal Czech geol. Soc., 38, 165-170.

- (1996): Tourmaline and associated minerals in alkali-feldspar orthogneiss near Hluboká nad Vltavou, southern Bohemia. Journal Czech geol. Soc., 41, 191-200.

Procházka, Z., et al. (1979): Přibyslavice - závěrečná zpráva. - MS Geoindustria Praha.

Rajlich, P. - Peucat, J. J. - Kantor, J. - Rychtár, J. (1992): Variscan shearing in the Moldanubian of the Bohemian Massif: Deformation, gravity, K-Ar and Rb-Sr data for the Choustník Prevariscan orthogneiss. - Jb. Geol. B.-A., 134, 579-595. Wien.

Slabý, J. (1991): Petrologie a geochemie ortorul moldanubika jižních Čech. 232 p. - MS ČGÚ Praha.

Štěpánek, P. (1996): Geologická mapa ČR 1:50 000, list 13-43 Golčův Jeníkov. - Česká geologická služba Praha.

Vrána, S. - Kröner, A. (1995): Pb-Pb zircon ages for tourmaline alkalifeldspar orthogneiss from Hluboká nad Vltavou in southern Bohemia. - Journal Czech. Geol. Soc., 40, 127-131.

Zikmund, J. (1983): Relict granites and the genesis of the Blaník orthogneisses (Bohemian Massif). - Časopis Mineral. Geol., 28, 8187, (in Czech with English summary).

\section{Appendix}

Whole rock analyses were performed in chemical laboratory of CGS Praha: major elements by wet chemistry, trace elements $\mathrm{As}$, $\mathrm{Cu}, \mathrm{Nb}$, Rb, $\mathrm{Sn}$, Zn and $\mathrm{Zr}$ in all samples by XRF and REE in some samples (in italic in Table 2) by ICP-OES. Other trace elements and REE were analysed by ICP-MS in ACME Vancouver.

Trace elements in biotites were analysed from monomineralic concentrates (more than $99 \%$ purity) by wet chemistry in laboratory of CGS Praha.

Rock-forming minerals (feldspar, micas, tourmaline) from locality Přibyslavice were analysed in laboratory of CGS Praha using CamScan 4-90DV electron microscope equipped with LINK eXL X-ray analyser. Rock-forming minerals from other localities were analysed in laboratory of Geological institute of Academy of Science of Czech Republic in Praha on the CAMECA SX100 microprobe in WDS mode.

Microprobe analyses of accessory minerals and dating of monazite were performed in Joint laboratory of electron microscopy and microanalysis of CGS and Masaryk University in Brno. For more analytical details see Breiter et al. (2005) and Breiter - Sulovský (2005).

\section{Chemické a minerální složení ortorul severovýchodní části moldanubika}

V severovýchodní části moldanubika, východně od blanické brázdy, jsou rozlišovány dva základní typy spodně paleozoických ortorul. Biotitické ortoruly se vyskytují na periferii oblasti, kdežto leukokrátní dvojslídné a muskovit-turmalinické ortoruly tvoří pruh výskytu orientovaný SV-JZ ve střední části oblasti. Oba typy ortorul jsou peraluminické. Nejvíce frakcionované typy leukokrátních ortorul jsou obohaceny borem, fosforem, cínem a wolframem a svým chemickým složením se blíží cínonosným granitům. Z mineralogického hlediska je typické obohacení obou živců (K-živce a albitu) fosforem, častá př́itomnost turmalínu a výskyt fosforem obohaceného granátu almandin-spessatinového složení. Zirkon z frakcionovaných ortorul je často zonární a obohacený o P, U, Al, Fe a Sc. Pokus o využití monazitu pro určení stáŕí magmatického protolitu ortorul pomocí analýzy U-Th-Pb na mikrosondě se nezdařil - všechna zjištěná stáŕí ekvilibrace jsou variská (316-327 Ma). Nicméně z hlediska chemické a minerální podobnosti studovaných ortorul a spolehlivě datované hlubocké ortoruly lze všechny tyto ortoruly považovat za produkt jedné rozsáhlé spodně paleozoické magmatické události, která postihla celé sv. moldanubikum. Tavením (meta)-sedimentárních hornin bohatých muskovitem vznikaly peraluminické taveniny blízké granitovému minimu, současně však obohacené borem. Následná frakcionace vedla k obohacení fosforem a cínem. Nejsilněji frakcionované ortoruly tvoří na dnešním povrchu pruh mezi Blaníkem na JZ a Přibyslavicemi u Čáslavi na SV. 